\title{
The Numbers Behind Mushroom Biodiversity
}

\author{
Anabela Martins
}

Polytechnic Institute of Bragança, School of Agriculture (IPB-ESA), Portugal

\subsection{Origin and Diversity of Fungi}

Fungi are difficult to preserve and fossilize and due to the poor preservation of most fungal structures, it has been difficult to interpret the fossil record of fungi. Hyphae, the vegetative bodies of fungi, bear few distinctive morphological characteristicss, and organisms as diverse as cyanobacteria, eukaryotic algal groups, and oomycetes can easily be mistaken for them (Taylor \& Taylor 1993). Fossils provide minimum ages for divergences and genetic lineages can be much older than even the oldest fossil representative found. According to Berbee and Taylor (2010), molecular clocks (conversion of molecular changes into geological time) calibrated by fossils are the only available tools to estimate timing of evolutionary events in fossil-poor groups, such as fungi.

The arbuscular mycorrhizal symbiotic fungi from the division Glomeromycota, generally accepted as the phylogenetic sister clade to the Ascomycota and Basidiomycota, have left the most ancient fossils in the Rhynie Chert of Aberdeenshire in the north of Scotland (400 million years old). The Glomeromycota and several other fungi have been found associated with the preserved tissues of early vascular plants (Taylor et al. 2004a). Fossil spores from these shallow marine sediments from the Ordovician that closely resemble Glomeromycota spores and finely branched hyphae arbuscules within plant cells were clearly preserved in cells of stems of a $400 \mathrm{Ma}$ primitive land plant, Aglaophyton, from Rhynie chert 455-460 Ma in age (Redecker et al. 2000; Remy et al. 1994) and from roots from the Triassic (250-199 Ma) (Berbee \& Taylor 2010; Stubblefield et al. 1987).

Many other fungal preserved materials have been found and a very well-preserved Ascomycota fungal fossil (Paleopyrenomycites devonicus), consisting of perithecia immersed within stems of a Devonian plant (Asteroxylon mackiei Kidston and Lang), provides a minimum age for the Ascomycota and Basidiomycota at $452 \mathrm{Ma}$ (Berbee \& Taylor 2010; Taylor \& Gaines 1999, 2004b, 2005). Basidiomycota is the sister group to the Ascomycota and the two phyla must be the same age. Basidiomycota are diagnosed by the hyphae with clamp connections and in modern ecosystems clamped hyphae permeate soil and organic matter. The oldest convincing basidiomycete fossils are of hyphal 
clamp connections from a Carboniferous coal ball (Pennsylvanian age, 299-318 Ma), which are much younger than even the minimum age of Ascomycota at $452 \mathrm{Ma}$ (Berbee \& Taylor 2010).

Fungi are an ancient group of organisms and their earliest fossils are from the Ordovician, 460-455 million years old (Redecker et al. 2000). Based on fossil evidence, the earliest vascular land plants appeared approximately 425 million years ago, and it is believed that fungi may have played an essential role in the colonization of land (Carris et al. 2012; Redeker et al. 2000). Mushroom structures preserved in amber from the Late Cretaceous (94 million years ago) are evidence that mushroom-forming fungi similar to those that exist today already existed when dinosaurs roamed the planet (Hibbett et al. 2003). However, the fungal fossil record is incomplete and provides only a minimum time estimate for when different groups of fungi evolved. Molecular data suggest that fungi are much older than indicated by the fossil record, and may have arisen more than 1 billion years ago, but the development of a mutually corroborating body of fossil and phylogenetic evidence is needed to clarify the evolution of organisms on Earth (Berbee \& Taylor 2010; Carris et al. 2012; Parfrey et al. 2011).

Fungi were not fixed geographically but rather, fungal ranges changed more recently and dynamically through long-distance dispersal. The same geographical barriers affecting the spread of plants and animals also limited the historical spread of fungi. Fungi are not simply ancient and unchanging, but have evolved just as dynamically as any other group of eukaryotes (Berbee \& Taylor 2010).

The kingdom Fungi is one of the most diverse groups of organisms on Earth (Tedersoo et al. 2014). The fungi are a distinct group of organisms more closely related to animals than plants (FAO 2004). By their descent from an ancestor shared with animals about a billion years ago plus or minus 500 million years (Berbee \& Taylor 2010), the fungi constitute a major eukaryotic lineage equal in numbers to animals and exceeding plants. The kingdom Fungi, distinct from plants and animals, became gradually accepted after Whittaker's classification (1969) (Abdel-Azeem 2010). Although the concept of the Fungi as one of the six kingdoms of life was introduced by Jahn \& Jahn (1949) and a five kingdom system had been advanced by Whittaker (1959), neither of these works included a Latin diagnosis and the name was therefore invalid under the International Code of Botanical Nomenclature, until the required Latin description was provided by Moore in 1980 (Hibbet 2007). Presently, the extremely diverse group of organisms studied as "fungi" span three kingdoms, most belonging to the Fungi (Eumycota), while others are classified in the Protozoa and Chromista (Straminipila) (Abdel-Azeem 2010; Cavalier-Smith 1998; James et al. 2006). The word "fungi," lower case and not in italics, is commonly used as a collective term for organisms from all three kingdoms traditionally studied by mycologists (Abdel-Azeem 2010; Hawksworth 1991).

Estimates for the number of fungi in the world have been suggested by many authors and range up to ca. 13.5 million species (Adl et al. 2007; Blackwell 2011; Crous et al. 2006; Hawksworth 1991, 2001; Hawksworth \& Kalin-Arroyo 1995; Hyde 1996; Hyde et al. 1997; Kirk et al. 2008; McNeely et al. 1990). It might be expected that the predicted numbers of fungi on Earth would have been considerably greater than the 1.5 million suggested by Hawksworth (1991), based on ratios of known fungi to plant species in regions where fungi were considered to be well studied, which is currently accepted as a working figure although recognized as conservative because numerous potential fungal habitats and localities remain understudied 
(Hawksworth 2001). This was based on a fungus to plant ratio of 6:1, in contrast to the much lower estimates suggested by Bisby and Ainsworth (1943) of 100000 fungal species and by Martin (1951) of 250000 species based on one fungus for every phanerogam known at the time (Blackwell 2011). Analysis of environmental DNA samples from a soil community revealed a high rate of new species accumulation at the site, and these data supported an estimate of 3.5-5.1 million species according to O'Brien et al. (2005) and Blackwell (2011).

According to the present data, higher estimates of land plant numbers are slightly under 400000 species (Joppa et al. 2010; Paton et al. 2008); fungal species numbers are expected to outnumber the land plant by 10.6:1 based on O'Brien et al. (2005). Higher ratios have even been predicted according to data from sequencing of clone libraries, although individual ecosystems will have variations. Fungi comprise some 100000 described species, but the actual extent of global fungal diversity is estimated at 0.8 million to 5.1 million species according to data acquired from several molecular methods (Blackwell 2011; O’Brien et al. 2005; Taylor et al. 2010).

The Dictionary of the Fungi (Kirk et al. 2008) reported 98998 species of all described fungi species (Figure 2.1) (excluding taxa treated under Chromista and Protozoa). The Dictionary estimated that known species has almost tripled in the period between the first edition in 1943 (38000 described species) and 2008, amounting to an increase of more than 60000 described species over the 65-year period (see Figure 2.1). Factors such as difficulty of isolation and failure to apply molecular methods may contribute to lower numbers of species in certain groups, but there cannot be any doubt that ascomycetes and basidiomycetes comprise the vast majority of fungal diversity (Figure 2.2) (Abdel-Azeem 2010; Blackwell 2011). Kirk et al. (2008) reported 1039 species as chromistan fungal analogues and 1165 as protozoan, in which 1038 are regarded as protozoan fungal analogues (Abdel-Azeem 2010).

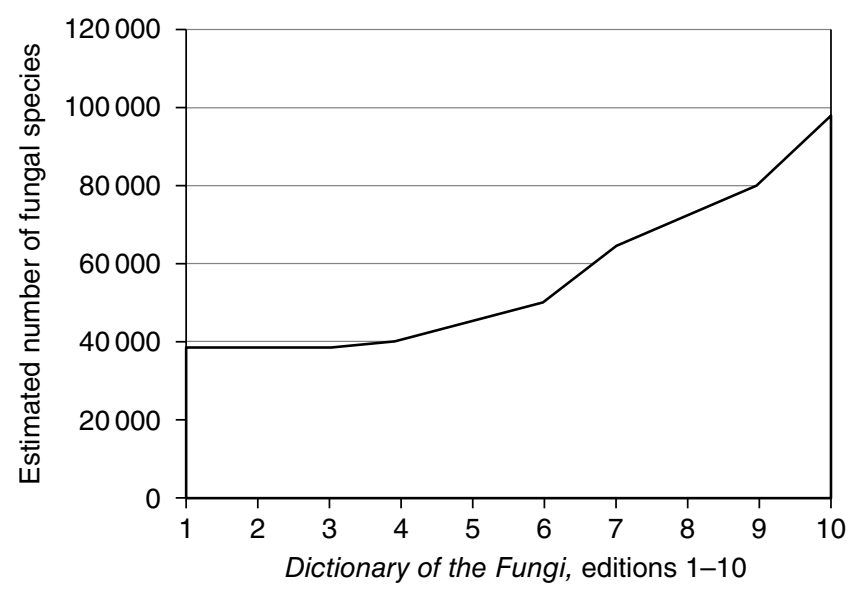

Figure 2.1 Numbers of known fungi from the Dictionary of the Fungi (editions 1-10, 1950-2008). Authors state that the large increase in species numbers in the 10th edition may be inflated because asexual and sexual forms were counted separately and molecular techniques that distinguish close taxa have been used. Source: reproduced with permission from Blackwell (2011). 


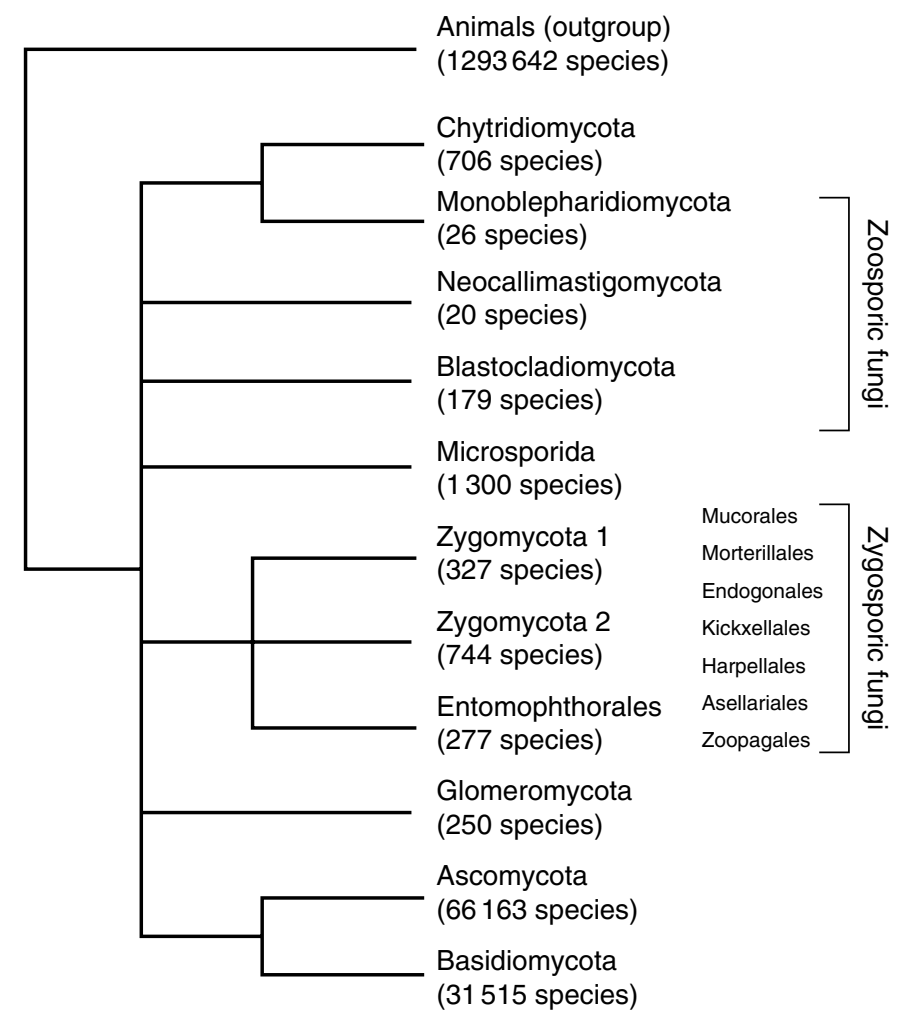

Figure 2.2 Fungal phyla and approximate number of species in each group (Kirk et al. 2008). Evidence from gene order conversion and multilocus sequencing indicates that microsporidians are Fungi (Lee et al. 2010). Zoosporic and zygosporic fungal groups are not supported as monophyletic. Tree based on Hibbett et al. (2007), White et al. (2006), and James et al. (2006). Source: reproduced with permission from Blackwell (2011).

\subsection{Ecological Diversity}

Fungi are eukaryotic microorganisms consisting of fine threads known as hyphae, which together form a mycelium, or yeast forms; they play fundamental ecological roles as decomposers, mutualists, and pathogens of plants and animals. They obtain their nutrients in three basic ways, depending on dead and living material for their nutrition and growth: saprobic, if they grow on dead organic matter; symbiotic, when growing in association with other organisms; parasitic, when causing harm to another organism. They drive carbon cycling in forest soils, mediate mineral nutrition of plants, and alleviate carbon limitations of other soil organisms (Blackwell 2011; FAO 2004).

Saprobic fungi are those that feed on dead or decomposing organic matter. In the absence of chlorophyll to synthesize carbon compounds from the atmosphere's $\mathrm{CO}_{2}$, such fungi secrete a number of enzymes which are able to decompose cellulose, hemicellulose, and lignin mainly from plants. Therefore, they have a mission of great ecological importance (Anguix 2011). They play a vital role in the life cycle of the biosphere, since all plant debris generated over time is mineralized and transformed into 
humus, thus recycling soil nutrients. This process involves the volatilization of carbon, hydrogen, and oxygen, and the release of nitrogen, phosphorus, potassium, sulfur, and many other elements. Saprobic fungi are provided with efficient enzyme complexes capable of degrading complex carbon sources such as cellulose, lignin or starch and transforming them into simple and nutritious molecules like sugars and amino acids. These enzymes show different degrees of effectiveness in the degradation of substrates, determining the degree of specialization of these fungi. While some fungi exploit organic matter of any origin, others prefer more specific substrates. Thus we find humus decomposing fungi, coprophilous and lignicolous, among others according to the decomposing substrate (Anguix 2011; Fernández-Toirán et al. 2011a).

Concerning fruiting body production, several authors point out that the proportion of saprobes to total macrofungi is generally low (Vogt et al. 1992), although this depends on the amount of debris that accumulates in the forest. The volume and value of saprobic wild species used as food are small by comparison with the symbiotic edible fungi, though more edible saprobic species are collected.

Symbiotic fungi include lichenized fungi and mycorrhizas as the main forms of association. The first symbiotic associations with algae and cyanobacteria (Fernández-Toirán et al. 2011a) and about $20 \%$ of all fungi and $40 \%$ of the ascomycetes (13500 species) are lichen-forming fungi (Lutzoni \& Miadlikowska 2009). Lichens and lichenized fungi are estimated to comprise about 20000 species (Feuerer \& Hawksworth 2007).

Mycorrhizal fungi form symbiotic associations with plant roots, forming mycorrhizae, a term first used by Frank (1885) to define the mutually beneficial partnership between the hyphae of a fungus and the roots of a plant. This partnership has proven to be of great importance in forest ecosystems.

Mycorrhizae are the most common symbiotic fungi association because they occur in more than $90 \%$ of the plant species, including bryophytes and ferns (Pressel et al. 2010). They are often essential to their plant hosts because they take up water, nitrogen, phosphorus, and other nutrients from the soil and transfer them to the plant roots. Some of these fungi may not prosper or even grow without the host. Certain mycorrhizal fungi specialize in orchids and ericoid plants, and some are known to have invaded new habitats with successful invasive plants (Pringle et al. 2009).

There are two main types of mycorrhizal fungi associations: arbuscular mycorrhizae (AM) and ectomycorrhizae (ECM). AM associations are more common and occur with up to $80 \%$ of all plant species and $92 \%$ of plant families. AM fungi are all included in the phylum Glomeromycota, a group with about 250 described species in a variety of taxa, though less diverse than ectomycorrhizal fungi (Blackwell 2011; Schüßler \& Walker 2010; Schüßler et al. 2001; Wang \& Qiu 2006).

More than 6000 species, mostly of mushroom-forming Basidiomycota, form ectomycorrhizae with about $10 \%$ of all plant families although their importance in the forestry world is enormous, as are trees and shrubs belonging to the families Pinaceae, Fagaceae, Betulaceae, and Salicaceae, among others (Fernández-Toirán et al. 2011b). Greater host specificity usually occurs in the ectomycorrhizal fungus-plant associations than in AM associations (Blackwell 2011; Smith \& Read 2008).

A recent study has conservatively estimated global ectomycorrhizal fungal species richness at approximately 7750 species. However, on the basis of estimates of macromycete known and unknown diversity, a final estimate of ECM species richness would likely be between 20000 and 25000 (Rinaldi et al. 2008). 
Moreover, ectomycorrhizae-forming fungi include many of the most common species, mainly from the divisions Basidiomycota (Amanita spp., Boletus spp., Lactarius spp., Hebeloma spp., etc.) and Ascomycota (Tuber spp., Terfezia spp., etc.) (Fernández-Toirán et al. 2011b). The fruiting bodies of some of these species, mushrooms, have great economic interest, being highly appreciated for human consumption, such as boletus, chanterelles, and truffles.

Parasitic fungi are characterized by living in different hosts (plant, animal or fungi) to which they cause more or less serious damage or even death. If causing disease in the host, they are considered pathogens. They are biotrophic when they need to live of living cells and necrotrophic when they degrade the dead host as a saprobic (FernándezToirán et al. 2011b).

Although some zoosporic and zygosporic fungi are plant pathogens, most plant pathogens are Ascomycota and Basidiomycota. A large number of Ascomycota and ca. 8000 species of Basidiomycota are plant pathogens (Blackwell 2011). Parasitic plant fungi play an important role in ecosystems, affecting competition between plant species and acting generally as balancing factors of the ecosystem. Thus, they can open holes in wood, creating microhabitats and favoring the establishment of other species, causing changes in the size and distribution of the plant population and increasing diversity. However, in monospecific forests and particularly in plantations of exotic species, fungi parasites can cause severe damage (Fernández-Toirán et al. 2011b).

Fungi have the ability to grow on and in both invertebrate and vertebrate animals. Many fungi can attack insects and nematodes; for example, they may play an important role in keeping populations of these animals under control. Insect-attacking fungi, called entomopathogens, include a wide range of fungi in phyla Ascomycota, Zygomycota, and Chytridiomycota (Carris et al. 2012).

There are relatively few fungal pathogens of vertebrates (only 200-300 species) but some of these fungi can have devastating impacts. Some examples are the frog killer, Batrachochytrium dendrobatidis Longcore, Pessier \& D.K. Nichols, a member of phylum Chytridiomycota, that is the only chytrid known to parasitize a vertebrate animal (amphibians), and the Ascomycota Geomyces destructans Blehert \& Gargas that causes "white-nose syndrome" in bats (Carris et al. 2012).

In humans, there are several different types of fungal infections, or mycoses. The most common are caused by dermatophytes, fungi that colonize dead keratinized tissue including skin, finger-, and toenails. Dermatophytes cause superficial infections such as ringworm that are unsightly and difficult to treat, but rarely serious. Some fungi are members of the resident microflora in healthy people, but become pathogenic in people with predisposing conditions, as, for example, Candida species. Another group of fungi are inhaled as spores and initiate infection through the lungs. These include Coccidioides immitis (coccidioidomycosis, commonly known as valley fever) and Histoplasma capsulatum (histoplasmosis) (Carris et al. 2012).

Parasitism can also occur between two fungi, such as Hypomyces lateritius that parasitize the hymenium of Lactarius deliciosus (L. ex Fr.) S.F.Gray, usually causing the disappearance of the lamellae. Another example is Sepedonium chrysospermum (Bull.) Fr. that parasitizes Boletus edulis Bull. Parasitism of some fungi on others suggests the existence of a natural biological control (Fernández-Toirán et al. 2011b).

Fungi grow in almost all habitats on Earth, surpassed only by bacteria in their ability to withstand extremes in temperature, water activity, and carbon source (Raspor \& Zupan 2006). 
Tropical regions of the world are considered to have the highest diversity for most groups of organisms (Hillebrand 2004), and this is generally true for fungi as well (Arnold \& Lutzoni 2007).

In temperate deserts mycorrhizal boletes, agarics, and rust and smut fungi are common. A surprising number of wood-decaying basidiomycetes have been discovered on living and dead desert plants, including cacti (Blackwell 2011).

Fungi also grow at very low temperatures as can be observed on the deterioration of historic shelters built by Antarctic explorers. Although there are not large numbers of species, it is important to consider this fungal habitat in diversity studies (Blackwell 2011; Held et al. 2005). In Arctic and Antarctic regions, lichens have often been reported (Wirtz et al. 2008), and yeasts are active under frozen conditions in the Antarctic (Amato et al. 2009; Vishniac 2006). In some cases, yeasts isolated from the Antarctic (based on 28S rDNA barcoding) have been reported from varied habitats, including human infections, the gut of insects, deep seas, and hydrocarbon seeps (Kurtzman \& Fell 1998). Although some fungi are specialized for cold regions, others simply occupy a wide variety of environmental conditions (Blackwell 2011).

Many regions and habitats of the world need to be included in fungal diversity studies, including the following (Blackwell 2011).

\subsubsection{Freshwater Fungi}

More than 3000 species of ascomycetes are specialized for a saprobic lifestyle in freshwater habitats where they have enhanced growth and sporulation (Kirk et al. 2008; Shearer \& Raja 2010; Shearer et al. 2007). Other fungi are present in water, and some of these are active in degrading leaves in streams. A few specialized freshwater basidiomycetes are also known. Flagellated fungi occur in aquatic habitats, including Chytridiomycota, Blastocladiomycota, and Monoblepharomycota (James et al. 2006). Batrachochytrium dendrobatidis, the recently described amphibian killer, is an aquatic chytrid (Longcore et al. 1999).

\subsubsection{Marine Fungi}

According to estimates performed by Hyde et al. (1998), 1500 species of marine fungi occur in a wide range of taxonomic groups. Many of these fungi are distinct from freshwater aquatic species, and they may be saprobic on aquatic plant substrates. Some species have characteristics such as sticky spore appendages, indicators of specialization for the marine habitat (Kohlmeyer et al. 2000). Most marine fungi are ascomycetes and basidiomycetes, including ascomycete and basidiomycete yeasts (Nagahama 2006). Some of the yeasts degrade hydrocarbon compounds present in natural underwater seeps and spills (Davies \& Westlake 1979). Certain ascomycetes are specialized on calcareous substrates, including mollusk shells and cnidarian reefs. Even a few mushroom-forming basidiomycetes are restricted to marine waters (Binder et al. 2006). Some fungi use other marine invertebrates as hosts (Kim \& Harvell 2004), including antibiotic producers that live in sponges (Bhadury et al. 2006; Pivkin et al. 2006; Wang et al. 2008). A wide variety of fungi considered to be terrestrial are also found in marine environments (Kurtzman \& Fell 1998; Morris et al. 2011; Murdoch et al. 2008). 


\subsubsection{Endophytes of Plant Leaves and Stems}

Most plants on Earth are infected with fungi endophytes, that do not cause disease symptoms (Saikkonen et al. 1998). Endophytes from a broad array of taxonomic groups occur between the cells of above-ground plant parts (Arnold 2007; Rodriguez et al. 2009). Some grass endophyte species produce alkaloid toxins effective against insects, other invertebrate animals, and vertebrates (Clay et al. 1993). Some grass endophytes are transmitted to the host offspring in seeds, and others inhibit sexual reproduction in the host and are dispersed within plant parts such as leaf fragments. For grass endophytes that reproduce sexually, fertilization may occur by insect dispersal. Infected hosts have increased water intake and these plants often have increased growth compared to uninfected hosts.

A much more diverse group of endophytic fungi are associated with a variety of dicots and conifers (Rodriguez et al. 2009), many from the ascomycetes group. In tropical habitats, plant leaves can acquire multiple infections as they mature, and there is strong evidence that the endophytes protect leaves of plants from infection when they were challenged with pathogens (Arnold et al. 2003). Vega and colleagues (2010) also found high diversity of endophytes in cultivated coffee plants. Interestingly, some of these were insect pathogens and experiments are being conducted to develop endophytes as biological control agents of insect pests.

\subsubsection{Fungi from Arthropod and Invertebrate Animals}

Arthropod and insect-associated fungi are poorly studied (Hawksworth 1991; Mueller \& Schmit 2007; Rossman 1994; Schmit \& Mueller 2007) but estimates of insect-associated fungi suggest the existence of 20000-50000 species (Rossman 1994; Schmit \& Mueller 2007; Weir \& Hammond 1997a,b). Insects may be food for fungi, especially in low nitrogen environments. Studies of the ectomycorrhizal basidiomycete Laccaria bicolor (Maire) P.D.Orton led to the surprise discovery that the fungus was not insect food but rather, the fungus and the host tree benefited by obtaining substantial amounts of nitrogen from the insects (Klironomos \& Hart 2001). The predatory habit has arisen independently on several occasions in at least four phyla of fungi and oomycetes. Predatory fungi such as Arthrobotrys and Dactylella trap, capture, or control nematodes and other small invertebrate animals in soils and wood (Barron 1977). Global estimates of arthropods were revised from 30 million to 5-10 million (Ødegaard 2000) and although not all insects and arthropods associate with fungi, the numbers of insectassociated fungi must be very high (Blackwell 2011).

\subsection{Global Diversity of Soil Fungi}

Fungi are broadly distributed in all terrestrial ecosystems and play major roles in ecosystem processes (soil carbon cycling, plant nutrition, pathology), but the distribution of species, phyla, and functional groups as well as the determinants of fungal diversity and biogeographic patterns are still poorly understood (Tedersoo et al. 2014).

The latitudinal gradient of diversity is a highly general spatial pattern of diversity with very few notable exceptions (Hillebrand 2004). At a global scale, the biomass and 
relative proportions of microbial groups vary with the concentration of growth-limiting nutrients in soils and plant tissues. The distribution of microbes may reflect latitudinal variation in ecosystem nutrient dynamics (Fierer et al. 2009; Serna-Chavez et al. 2013; Tedersoo et al. 2014; Xu et al. 2013). Richness of nearly all terrestrial and marine macroorganisms is negatively related to increasing latitude (Hillebrand 2004) as a result of the combined effects of climate, niche conservatism, and rates of evolutionary radiation and extinction (Mittelbach et al. 2007; Tedersoo et al. 2014).

Despite the enormous diversity and importance of fungi in ecosystem function, their general diversity patterns or functional roles over large geographic scales are poorly understood. Tedersoo et al. (2014) used a global dataset to unravel the roles of climatic, edaphic, floristic, and spatial variables governing global-scale patterns of soil fungal diversity. They also showed that fungi largely exhibit strong biogeographic patterns that appear to be driven by dispersal limitation and climate (Tedersoo et al. 2014).

The microscopic size and hidden existence of most below-ground organisms limit the knowledge of their global ecology; however, molecular techniques for analyzing soil communities have provided unprecedented opportunities for understanding soil biodiversity and testing whether global diversity patterns established for above-ground biota also apply to soil biota. Tedersoo et al. (2014) characterized fungal communities in soil samples from 365 separate locations worldwide (including all continents except Antarctica), all of which were sampled, processed, and analyzed by the same methods (Wardle \& Lindahl 2014).

At a global scale, mean annual precipitation seemed to be the strongest driver of the richness of fungal operational taxonomic units but soil properties, and particularly soil $\mathrm{pH}$ and calcium concentration, also had important positive effects. Soil fungi are generally considered as acidophiles when compared to bacteria but the current results suggest that, rather than a preference for acidic conditions, they have a wider range of $\mathrm{pH}$ tolerance (Tedersoo et al. 2014; Wardle \& Lindahl 2014).

The relative richness of the main functional fungi groups, ectomycorrhizae, saprotrophs, and pathogens, provides a wide variation among the major earth biomes, consistent with the separate set of factors affecting each group. Ectomycorrhizal fungal richness is most strongly related to the richness of host plant species and high soil $\mathrm{pH}$; saprotroph richness is positively related to mean annual precipitation; and pathogen richness is negatively related to latitude but positively related to nitrogen availability (Tedersoo et al. 2014; Wardle \& Lindahl 2014).

Total fungal richness increases toward the equator, in line with the general pattern of decline of species richness with increasing latitude (Hillebrand 2004; Taylor \& Gaines 1999), but major groups of fungi defy this pattern. Ectomycorrhizal fungal richness is greatest at mid- to high northern latitudes (coinciding with temperate and boreal forest), and richness within several ascomycete groups (notably the Leotiomycetes, which include fungi that form mycorrhizal associations with ericoid dwarf shrubs) increases toward the poles. Globally, fungal richness does not decline as sharply as plant species diversity with increasing latitude; the result is that the ratio of fungal to plant richness rises exponentially toward the poles. Fungi are thus a key component of total terrestrial biodiversity at high latitudes, with important implications for conservation. Reliable estimates of this ratio are important for deriving global fungal diversity from measures of plant diversity. 
According to Tedersoo et al. (2014), at a global scale the best predictors of fungal richness and community composition are climatic factors, followed by edaphic and spatial variables. Richness of all fungi and functional groups is causally unrelated to plant diversity, ectomycorrhizal root symbionts being the exception. They emphasize that plant-to-fungi richness ratios decline exponentially toward the poles, and that predictions assuming globally constant ratios can overestimate fungal richness by 1.5-2.5fold. Similar biogeographic patterns were found for fungi, plants and animals, with the exception of several major taxonomic and functional groups that run counter to overall patterns. Fungi exhibited strong biogeographic links among distant continents, revealing a relatively efficient long-distance dispersal compared with macroorganisms (Tedersoo et al. 2014).

\subsection{Wild Edible Fungi}

Wild edible mushrooms have been collected and consumed by people for thousands of years. Since time immemorial, a considerable number of identified species of fungi have made a significant contribution to human food and medicine.

The use of edible species by people living in Chile 13000 years ago is documented in archaeological records (Rojas \& Mansur 1995). China has a history of consumption and use of wild mushrooms that was first reliably noticed several hundred years before Christ (Aaronson 2000). Edible mushrooms were gathered in the forests during Greek and Roman antiquity, but were appreciated mainly by people of higher status (Buller 1914). The Roman Empire is well known for the mushroom consumption of its emperors, who employed food tasters to ensure that the mushrooms were safe to eat (Jordan 2006). The Caesar mushroom (Amanita caesarea (Scop.) Pers.) refers to an ancient Italian tradition that still exists in many parts of Italy, using a diversity of edible species dominated today by truffles (Tuber spp.) and porcini (Boletus edulis). In China, many wild mushroom species have been valued for centuries, not only for food but also for their medicinal properties. These values and traditions are still highly relevant today and are confirmed by the wide range of wild mushrooms picked from the forests and fields. China also leads the exports of cultivated mushrooms (FAO 2004; FAOStat 2015).

The tradition of wild edible mushroom use exists from ancient times in many countries. Although less well known, countries like Mexico and Turkey and vast areas of Central and Southern Africa also have a long and important tradition of edible wild mushrooms. The list of countries where wild mushrooms are consumed and provide earnings to rural people is very long and widespread around the world (Table 2.1) (FAO 2004).

The list of wild useful fungi (edible, medicinal and other uses) (see Table 2.1) includes over 2800 records from 85 countries and was prepared from a preliminary database record of published information. The mycological literature is extensive in many developed countries but often there is no clear indication of which species are eaten as food. Only uses of practical or economic importance have been included; ceremonial or religious uses are omitted. In Table 2.1 are shown the total number of useful species and the main number of species with each of the uses (edible, food, medicinal, cosmetic and other, such as tinder, jewellery, spice, perfume, etc.) in each of the 85 countries. For details on the names of the species used in each country, Annex 2 of FAO (2004) can be consulted. 
Table 2.1 Country records of wild useful fungi (edible, medicinal, and other uses).

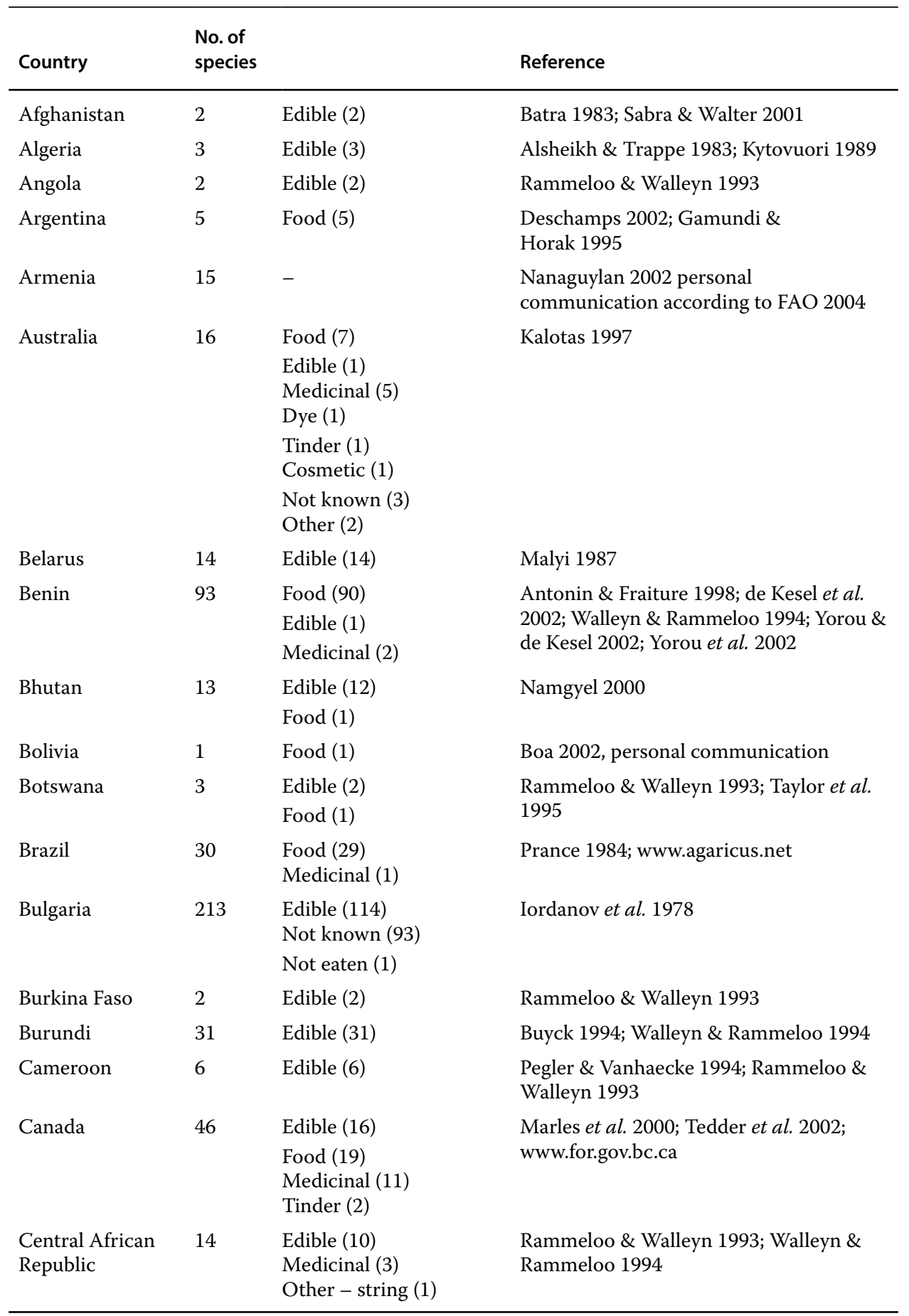


Table 2.1 (Continued)

\begin{tabular}{|c|c|c|c|}
\hline Country & $\begin{array}{l}\text { No. of } \\
\text { species }\end{array}$ & & Reference \\
\hline Chile & 24 & $\begin{array}{l}\text { Food (8) } \\
\text { Edible (16) } \\
\text { Medicinal (1) }\end{array}$ & $\begin{array}{l}\text { FAO 1998; Minter et al. 1987; Schmeda- } \\
\text { Hirschmann et al. } 1999\end{array}$ \\
\hline China & 220 & $\begin{array}{l}\text { Medicinal (19) } \\
\text { Food (10) } \\
\text { Not edible (2) } \\
\text { Edible (186) } \\
\text { Not known (2) }\end{array}$ & $\begin{array}{l}\text { Birks 1991; Cao 1991; Chamberlain 1996; } \\
\text { Dong \& Shen 1993; Gong \& Peng 1993; } \\
\text { Hall et al. 1998; Härkönen 2002; He 1991; } \\
\text { Huang 1989; Li 1994; Liu 1990; Liu \& } \\
\text { Yang 1982; Guozhong 2002, personal } \\
\text { communication; Pegler \&Vanhaecke } \\
\text { 1994; Tu 1987; Winkler 2002; www.zeri. } \\
\text { org; Xiang \& Han, 1987; Yang 1990, 1992; } \\
\text { Yang \& Yang 1992; Zang 1984, 1988; Zang \& } \\
\text { Petersen 1990; Zang \& Pu 1992; Zang \& } \\
\text { Yang 1991; Zhuang 1993; Zhuang \& } \\
\text { Wang } 1992\end{array}$ \\
\hline $\begin{array}{l}\text { Congo } \\
\text { (Democratic } \\
\text { Republic) }\end{array}$ & 110 & $\begin{array}{l}\text { Medicinal (2) } \\
\text { Edible (107) } \\
\text { Other - jewelry (1) }\end{array}$ & $\begin{array}{l}\text { Degreef et al. 1997; Pegler \& Vanhaecke } \\
\text { 1994; Rammeloo \& Walleyn 1993; } \\
\text { Walleyn \& Rammeloo } 1994\end{array}$ \\
\hline Congo (Republic) & 6 & Edible (6) & Rammeloo \& Walleyn 1993 \\
\hline Costa Rica & 59 & $\begin{array}{l}\text { Hallucinogen (5) } \\
\text { Poisonous (1) } \\
\text { Edible (60) }\end{array}$ & Saenz et al. 1983 \\
\hline Cote d'Ivoire & 4 & $\begin{array}{l}\text { Edible (3) } \\
\text { Food (1) }\end{array}$ & $\begin{array}{l}\text { Ducousso et al. 2002; Locquin 1954; } \\
\text { Pegler \& Vanhaecke 1994; Rammeloo \& } \\
\text { Walleyn } 1993\end{array}$ \\
\hline Egypt & 3 & Edible (3) & Zakhary et al. 1983 \\
\hline Ethiopia & 2 & Edible (2) & Tuno 2001 \\
\hline Fiji & 1 & Food (1) & Markham 1998 \\
\hline Gabon & 5 & $\begin{array}{l}\text { Edible (2) } \\
\text { Medicinal (2) } \\
\text { Other - string (1) }\end{array}$ & $\begin{array}{l}\text { Rammeloo \& Walleyn 1993; Walleyn \& } \\
\text { Rammeloo 1994, Note: another } 15+\text { types } \\
\text { are listed in Walker 1931, by local name } \\
\text { only }\end{array}$ \\
\hline Ghana & 17 & $\begin{array}{l}\text { Edible (12) } \\
\text { Medicinal (6) } \\
\text { Food (1) }\end{array}$ & $\begin{array}{l}\text { Ducousso et al. 2002; Obodai \& } \\
\text { Apetorgbor 2001; Rammeloo \& Walleyn } \\
\text { 1993; Walleyn \& Rammeloo } 1994\end{array}$ \\
\hline Guatemala & 38 & Food (38) & $\begin{array}{l}\text { Flores et al. 2002, personal } \\
\text { communication }\end{array}$ \\
\hline Guinea & 1 & Edible (1) & Walleyn \& Rammeloo 1994 \\
\hline Guyana & 1 & Edible (1) & Simmons et al. 2002 \\
\hline $\begin{array}{l}\text { Hong Kong } \\
\text { Special } \\
\text { Administrative } \\
\text { Region, China }\end{array}$ & 251 & $\begin{array}{l}\text { Edible (189) } \\
\text { Medicinal (113) }\end{array}$ & Chang \& Mao 1995 \\
\hline
\end{tabular}


Table 2.1 (Continued)

\begin{tabular}{|c|c|c|c|}
\hline Country & $\begin{array}{l}\text { No. of } \\
\text { species }\end{array}$ & & Reference \\
\hline India & 83 & $\begin{array}{l}\text { Edible (64) } \\
\text { Medicinal (8) } \\
\text { Other - spice (2) } \\
\text { Other - perfume (1) } \\
\text { Food (6) }\end{array}$ & $\begin{array}{l}\text { Birks 1991; Boruah et al. 1996; Singh \& } \\
\text { Rawat 2000; Harsh et al. 1996; Pegler \& } \\
\text { Vanhaecke 1994; Purkayastha \& Chandra } \\
\text { 1985; Richardson 1991; Sarkar et al. } \\
\text { 1988; Sharda et al. 1997; Sharma \& } \\
\text { Doshi } 1996\end{array}$ \\
\hline Indonesia & 7 & $\begin{array}{l}\text { Food (6) } \\
\text { Medicinal (1) } \\
\text { Edible (1) }\end{array}$ & Burkhill 1935; Ducousso et al. 2002 \\
\hline Iraq & 3 & $\begin{array}{l}\text { Edible (3) } \\
\text { Food (1) }\end{array}$ & $\begin{array}{l}\text { Al-Naama et al. 1988; Alsheikh \& Trappe } \\
1983\end{array}$ \\
\hline Israel & 3 & Edible (3) & Wasser 1995 \\
\hline Jordan & 9 & $\begin{array}{l}\text { Food (7) } \\
\text { Edible (2) }\end{array}$ & $\begin{array}{l}\text { Ereifej \& Al-Raddad 2000; Sabra \& } \\
\text { Walter } 2001\end{array}$ \\
\hline Kenya & 11 & $\begin{array}{l}\text { Edible (5) } \\
\text { Medicinal (2) } \\
\text { Other - dye (2) } \\
\text { Hallucinogen (2) } \\
\text { Poisonous (1) }\end{array}$ & $\begin{array}{l}\text { Pegler \& Vanhaecke 1994; Rammeloo \& } \\
\text { Walleyn 1993; Walleyn \& Rammeloo } 1994\end{array}$ \\
\hline Korea & 1 & Edible (1) & Wang et al. 1997 \\
\hline Kuwait & 2 & $\begin{array}{l}\text { Edible (1) } \\
\text { Food (1) } \\
\text { Medicinal (1) }\end{array}$ & Alsheikh \& Trappe 1983 \\
\hline Kyrgyzstan & 32 & Edible (32) & EI’chibaev 1964 \\
\hline Laos & 28 & $\begin{array}{l}\text { Edible (19) } \\
\text { Food (5) } \\
\text { Medicinal (3) } \\
\text { Other (1) }\end{array}$ & $\begin{array}{l}\text { Hosaka 2002, personal communication; } \\
\text { http//giechgroup.hp.infoseek.co.jp/ } \\
\text { kinoko/eng.html }\end{array}$ \\
\hline Lesotho & 1 & Edible (1) & Rammeloo \& Walleyn 1993 \\
\hline $\begin{array}{l}\text { Libyan Arab } \\
\text { Jamahiriya }\end{array}$ & 2 & Edible (2) & Alsheikh \& Trappe 1983 \\
\hline Madagascar & 75 & $\begin{array}{l}\text { Edible (72) } \\
\text { Food (1) } \\
\text { Medicinal (1) } \\
\text { Other - dye (1) }\end{array}$ & $\begin{array}{l}\text { Bouriquet 1970; Ducousso et al. 2002; } \\
\text { Rammeloo \& Walleyn 1993; Richardson } \\
\text { 1991; Walleyn \& Rammeloo } 1994\end{array}$ \\
\hline Malawi & 76 & $\begin{array}{l}\text { Edible (75) } \\
\text { Medicinal (1) } \\
\text { Hallucinogen (1) } \\
\text { Poisonous (1) } \\
\text { Insecticidal (1) }\end{array}$ & $\begin{array}{l}\text { Rammeloo \& Walleyn 1993; Walleyn \& } \\
\text { Rammeloo 1994; see also www. } \\
\text { malawifungi.org }\end{array}$ \\
\hline Malaysia & 7 & $\begin{array}{l}\text { Edible (6) } \\
\text { Food (1) }\end{array}$ & Burkhill 1935; Pegler \& Vanhaecke 1994 \\
\hline Mauritius & 5 & Edible (5) & $\begin{array}{l}\text { Rammeloo \& Walleyn 1993; Walleyn \& } \\
\text { Rammeloo } 1994\end{array}$ \\
\hline
\end{tabular}


Table 2.1 (Continued)

\begin{tabular}{|c|c|c|c|}
\hline Country & $\begin{array}{l}\text { No. of } \\
\text { species }\end{array}$ & & Reference \\
\hline Mexico & 307 & $\begin{array}{l}\text { Edible (119) } \\
\text { Food (180) } \\
\text { Medicinal (16) } \\
\text { Insecticidal (2) } \\
\text { Hallucinogen (1) } \\
\text { Other - dye (1) }\end{array}$ & $\begin{array}{l}\text { Lopez et al. 1992; Mata 1987; } \\
\text { Montoya-Esquivel 1998; } \\
\text { Montoya-Esquivel et al. 2001; } \\
\text { Moreno-Fuentes et al. 1996; } \\
\text { Richardson 1991; Villarreal \& } \\
\text { Perez-Moreno 1989; www.semarnat. } \\
\text { gob.mx; Zamora-Martinez et al. 2000; } \\
\text { Zamora-Martinez et al. } 1994\end{array}$ \\
\hline Mozambique & 22 & Food (22) & Uaciquete et al. 1996; Wilson et al. 1989 \\
\hline Morocco & 12 & $\begin{array}{l}\text { Edible (10) } \\
\text { Other - perfume (2) }\end{array}$ & $\begin{array}{l}\text { Alsheikh \& Trappe 1983; Kytovuori 1989; } \\
\text { Moreno-Arroyo et al. 2001; Richardson } \\
\text { 1991; FAO } 2001\end{array}$ \\
\hline Myanmar & 1 & Edible (1) & Pegler \& Vanhaecke 1994 \\
\hline Namibia & 4 & $\begin{array}{l}\text { Edible (2) } \\
\text { Medicinal (1) } \\
\text { Cosmetic (1) } \\
\text { Food (1) }\end{array}$ & $\begin{array}{l}\text { Rammeloo \& Walleyn 1993; Taylor et al. } \\
\text { 1995; Walleyn \& Rammeloo } 1994\end{array}$ \\
\hline Nepal & 98 & $\begin{array}{l}\text { Edible (41) } \\
\text { Medicinal (8) } \\
\text { Food (32) } \\
\text { Other - perfume (1) }\end{array}$ & $\begin{array}{l}\text { Adhikari 1999; Adhikari \& Durrieu 1996; } \\
\text { Richardson 1991; Zang \& Doi } 1995\end{array}$ \\
\hline Nigeria & 23 & $\begin{array}{l}\text { Edible (4) } \\
\text { Food (16) } \\
\text { Medicinal (6) } \\
\text { Cosmetic (1) } \\
\text { Poisonous (1) } \\
\text { Animal poison (1) }\end{array}$ & $\begin{array}{l}\text { Alofe et al. 1996; Oso 1975; Rammeloo \& } \\
\text { Walleyn 1993; Walleyn \& Rammeloo } 1994\end{array}$ \\
\hline Pakistan & 21 & Edible (21) & $\begin{array}{l}\text { Batra 1983; Gardezi 1993; FAO 1993; } \\
\text { Pegler \& Vanhaecke 1994; Syed-Riaz \& } \\
\text { Mahmood-Khan } 1999\end{array}$ \\
\hline $\begin{array}{l}\text { Papua New } \\
\text { Guinea }\end{array}$ & 36 & $\begin{array}{l}\text { Edible }(26) \\
\text { Not eaten }(8) \\
\text { Other - raw material }(1)\end{array}$ & Sillitoe 1995 \\
\hline Peru & 16 & $\begin{array}{l}\text { Edible (15) } \\
\text { Food (1) }\end{array}$ & $\begin{array}{l}\text { Diez 2003, personal communication: } \\
\text { Collecting Boletus edulis Bull. for } \\
\text { commercial purposes in Peru; Remotti \& } \\
\text { Colan } 1990\end{array}$ \\
\hline Philippines & 7 & $\begin{array}{l}\text { Edible (3) } \\
\text { Food (4) }\end{array}$ & Novellino 1999; Pegler \& Vanhaecke 1994 \\
\hline Poland & 14 & Food (14) & www.grzyby.pl \\
\hline Réunion & 1 & Edible (1) & Rammeloo \& Walleyn 1993 \\
\hline
\end{tabular}


Table 2.1 (Continued)

\begin{tabular}{|c|c|c|c|}
\hline Country & $\begin{array}{l}\text { No. of } \\
\text { species }\end{array}$ & & Reference \\
\hline $\begin{array}{l}\text { Russian } \\
\text { Federation }\end{array}$ & 240 & $\begin{array}{l}\text { Edible (226) } \\
\text { Poisonous (1) } \\
\text { Not known (7) } \\
\text { Medicinal (3) } \\
\text { Not Edible (7) }\end{array}$ & $\begin{array}{l}\text { Saar 1991; Vasil'eva, 1978; Note: This is } \\
\text { only for the Russian far east }\end{array}$ \\
\hline Saudi Arabia & 3 & $\begin{array}{l}\text { Edible (3) } \\
\text { Food (1) }\end{array}$ & $\begin{array}{l}\text { Alsheikh \& Trappe 1983; Bokhary \& } \\
\text { Parvez 1993; Kirk et al. } 2001\end{array}$ \\
\hline Senegal & 13 & $\begin{array}{l}\text { Edible (10) } \\
\text { Food (2) } \\
\text { Medicinal (1) }\end{array}$ & Ducousso et al. 2002 ; Thoen \& Ba 1989 \\
\hline Sierra Leone & 1 & Edible (1) & Pegler \& Vanhaecke 1994 \\
\hline Singapore & 1 & Food (1) & Burkhill 1935 \\
\hline Slovenia & 23 & $\begin{array}{l}\text { Edible (22) } \\
\text { Not Edible (1) }\end{array}$ & www.matkurja.com \\
\hline Somalia & 2 & Edible (2) & Rammeloo \& Walleyn 1993 \\
\hline South Africa & 11 & $\begin{array}{l}\text { Edible (9) } \\
\text { Hallucinogen (2) } \\
\text { Poisonous (1) }\end{array}$ & $\begin{array}{l}\text { Pegler \& Vanhaecke 1994; Walleyn \& } \\
\text { Rammeloo } 1994\end{array}$ \\
\hline Spain & 61 & Food (61) & $\begin{array}{l}\text { Cervera \& Colinas 1997; Martinez et al. } \\
1997\end{array}$ \\
\hline Sri Lanka & 2 & Edible (2) & Pegler \& Vanhaecke 1994 \\
\hline Tanzania & 48 & $\begin{array}{l}\text { Edible (40) } \\
\text { Food (5) } \\
\text { Medicinal (4) } \\
\text { Not Eaten (1) }\end{array}$ & $\begin{array}{l}\text { Härkönen et al. 1994a, 1994b; Rammeloo \& } \\
\text { Walleyn 1993; Walleyn \& Rammeloo } 1994\end{array}$ \\
\hline Thailand & 20 & Food (20) & $\begin{array}{l}\text { Jones et al. 1994; Pegler \& Vanhaecke } \\
\text { 1994; Stamets } 2000\end{array}$ \\
\hline Turkey & 49 & $\begin{array}{l}\text { Edible (30) } \\
\text { Food (19) }\end{array}$ & $\begin{array}{l}\text { Afyon 1997; Caglarirmak et al. 2002; } \\
\text { Demirbas 2000; Sabra \& Walter 2001; } \\
\text { http//www.ogm.gov.tri; Yilmaz et al. } 1997\end{array}$ \\
\hline Uganda & 10 & Edible (10) & $\begin{array}{l}\text { Katende et al. 1999; Pegler \& Vanhaecke } \\
\text { 1994; }\end{array}$ \\
\hline Ukraine & 160 & Edible (160) & Zerova \& Rozhenko 1988 \\
\hline Uruguay & 7 & Food (7) & Deschamps 2002 \\
\hline $\begin{array}{l}\text { United States } \\
\text { of America }\end{array}$ & 83 & $\begin{array}{l}\text { Edible (71) } \\
\text { Medicinal (11) } \\
\text { Food (1) }\end{array}$ & $\begin{array}{l}\text { Birks 1991; Lincoff \& Mitchel 1977; } \\
\text { Singer 1953; www.mykoweb.com }\end{array}$ \\
\hline Vietnam & 1 & Food (1) & Burkhill 1935 \\
\hline $\begin{array}{l}\text { Yugoslavia } \\
\text { (now Serbia And } \\
\text { Montenegro) }\end{array}$ & 4 & $\begin{array}{l}\text { Food ( } 3 \text { ) } \\
\text { Other - perfume (1) }\end{array}$ & Richardson 1988; Zaklina 1998 \\
\hline Zambia & 23 & $\begin{array}{l}\text { Edible (4) } \\
\text { Food (18) } \\
\text { Medicinal (1) }\end{array}$ & $\begin{array}{l}\text { Pegler \& Piearce 1980; Piearce 1981; } \\
\text { Rammeloo \& Walleyn 1993; Walleyn \& } \\
\text { Rammeloo } 1994\end{array}$ \\
\hline Zimbabwe & 12 & Food (12) & Boa et al. 2000 \\
\hline
\end{tabular}


Mushrooms can make a substantial contribution to the diet of poor people in developing countries but they can also be an important source of income. The list of countries where wild fungi are reported to be consumed and provide income to rural people is impressive. Wild edible fungi are sold in many local markets and commercial harvesting has provided new sources of income for many rural people (Arora 2008; FAO 2004).

\subsubsection{Diversity of Wild Edible Mushrooms}

Edible mushrooms are the fleshy and edible fruit bodies of several species of macrofungi (fungi that produce visible fruiting structures - mushrooms, carpophores or sporophores). They can appear either below ground (hypogeous) or above ground (epigeous) where they may be picked by hand (Chang \& Miles 1989). Edibility may be defined by criteria that include absence of poisonous effects on humans and desirable taste and aroma (Arora 1986; Rubel \& Arora 2008). Wild edible fungi are important for three main reasons:

- as a source of food (plus health benefits)

- as a source of income

- to maintain the health of forests (FAO 2004).

There are more than 200 genera of macrofungi which contain species of use to people, mostly because of their edible properties. The FAO (2004) makes a clear distinction between edible mushrooms and those that are consumed as food, since including all edible species as "food" would greatly outnumber the species consumed by people around the world (Table 2.2). A total of 1154 edible and food species was recorded, from

Table 2.2 Numbers of species of wild edible and medicinal fungi (FAO 2004).

\begin{tabular}{lcc}
\hline Category & No. of species & Percentage of total \\
\hline 1 Edible only & 1009 & 43 \\
2 Edible and medicinal & 88 & 4 \\
3 Food only & 820 & 35 \\
4 Food and medicinal & 249 & 11 \\
5 Medicinal only & 133 & 6 \\
6 Other uses (none of above) & 29 & 1 \\
TOTAL wild useful species & $\mathbf{2 3 2 7}$ & - \\
ALL edible only (1+2) & 1097 & - \\
ALL food (3+4) & 1069 & - \\
ALL medicinal $(2+4+5)$ & 470 & - \\
\hline
\end{tabular}

Note: Compiled from more than 200 different sources from 110 countries, but excludes a detailed review of species from developed countries. Varieties and subspecies are counted separately. The categories "food" and "edible" are mutually exclusive. To distinguish clearly between use and properties of a species, substantial numbers of edible species lack confirmed use as food. 
the total 2327 wild useful species compiled from 85 countries (see Table 2.2). The number of species eaten is sometimes only a fraction of those available. The species eaten in one country or region often differ from neighboring areas and in some cases there are dramatic changes in consumption tradition. The tradition of eating wild edible fungi goes from Mexico (180 species) to west Guatemala (38 species) then is absent from much of Honduras and Nicaragua, even though both contain forest areas that in theory support production of edible fungi.

The reasons for these different patterns of use are not always clear but there is a tendency of less frequent use as people move away from the land (FAO 2004; Rubel \& Arora 2008). Rural people in Guatemala have a positive and informed attitude of eating wild fungi which people living in cities lack (Lowy 1974). In Malawi, educated people living in towns have lost the strong local traditions that rural communities maintain and have even acquired a suspicious approach towards wild fungi (Lowore \& Boa 2001).

According to the FAO (2004) and Rubel and Arora (2008), the poorer the people, the more likely they are to use wild edible fungi. Some traditions are lost as people become better educated and live away from the land and they show an increasing reluctance to eat all but the most common species (Lowy 1974). In Korea, China, the Russian Federation, and Japan, the tradition of eating wild edible fungi is much stronger and seems to have resisted the changes experienced elsewhere (FAO 2004).

Many macrofungi are not worth eating even when they are not toxic. Others are simply inedible, lacking one or more of the above-described characteristics. In comparison, the number of toxic or poisonous species is very small, and just a very few are mortal. However, this very small group of lethal species has significantly influenced attitudes to eating wild fungi, creating mycophobic behavior and potential barriers to wider marketing in many places.

Before assuming that any wild mushroom is edible, it should be exactly identified. Accurate determination and proper identification of a species is the only safe way to ensure edibility, and the only protection against possible accidents. Some mushrooms that are edible for most people can cause allergic reactions in some individuals, and old or improperly stored specimens can cause food poisoning.

The risk associated with poisonous and lethal species is often exaggerated since occurrences of poisoning and deaths are few when compared to the regular and safe consumption of edible species. Publicity, cultural attitudes, and the increasing urban, nature-ignorant population continue to propagate an intrinsic fear of wild fungi in some societies (FAO 2004, 2009; Rubel \& Arora 2008). This is more commonly found in developed countries and has undoubtedly led to general beliefs that global use of wild edible fungi is small-scale and restricted to key areas, which is not true, as conclusively shown in FAO (2004) (see Table 2.1). The patterns of use of wild edible fungi are both extensive and intensive, though they do vary.

In addition to those different patterns of use, edibility is a feature that can generate conflicting reports in literature and in field guides. Some species are recommended as edible in some literature and rejected as poisonous in others (FAO 2004; Rubel \& Arora 2008). One of the cases of contradictory concepts about edibility is the false morel, Gyromitra esculenta (Pers. ex Pers.) Fr., that people from eastern Finland consider a delicacy after precooking, while guides in the United States and elsewhere consider that is poisonous and should not be eaten (FAO 2004). Some appropriate 
processing methods may render edible certain mushrooms reported as toxic, "poisonous" or not edible in mushroom field guides. For example, Boletus luridus Schaeff., Boletus erythropus Pers, and their close relatives are commonly eaten in China and Europe (especially Italy); Boletus satanas Lenz is eaten in Sicily after a complex cooking process; Boletus subvelutipes Peck is eaten in Japan and has been safely served for years by restaurants in Massachusetts; Gomphus floccosus Schw. (Singer) is commonly sold in the markets of Mexico and China; acrid, red-capped russulas such as Russula emetica (Schaeff.) Pers. are widely eaten after being cooked or salted; various peppery species of Lactarius such as Lactarius torminosus (Schaeff.) Pers. form an important part of the cuisine of northern European, Russia, and Siberia (Rubel \& Arora 2008).

Traditional knowledge is increasingly reported, as in the case of Korean communities which include 158 practices within 22 families, 33 genera, and 38 species of mushrooms, with Tricholomataceae (23.20\%), Pleurotaceae (13.10\%), Polyporaceae $(8.21 \%)$, and Hymenochaetaceae $(6.33 \%)$ as the most representative families. The results revealed 24 modes of preparation for the mushrooms, with the most common methods being seasoned cooked mushrooms (40.75\%), soups (13.84\%), teas $(12.18 \%)$, simmered $(9.19 \%)$, and roasted (6.20\%) (Kim \& Song 2014).

The major genera of wild edible fungi are described in Table 2.3, with brief notes on medicinal species. The wild edible fungi can be divided into two categories: those containing species that are broadly consumed and often exported in significant quantities, such as the genus Boletus and Cantharellus, and those with species that are eaten usually in small amounts and rarely exported (FAO 2004).

\subsubsection{Medicinal Mushrooms}

Useful macrofungi comprise species with edible and medicinal properties but distinction between the two categories is not easy. Many of the common edible species have therapeutic properties, thus several medicinal mushrooms are also eaten (see Table 2.3). The total number of useful fungi, defined as having edible and medicinal value, is estimated to be over 2300 species (see Table 2.2) (FAO 2004, 2009).

Ganoderma species are the most valuable medicinal mushrooms, with global values of the produced dietary supplements estimated as US\$1.6 billion (Chang \& Buswell 1999). Lentinula edodes (Berk.) Pegler and Volvariella volvacea (Bul. ex Fr.) Singer are also widely cultivated edible fungi with medicinal properties while Inonotus obliquus (Ach. ex Pers.) Pilát is the only noncultivated species out of the 25 more used medicinal species (Table 2.4).

The list of symbiotic macrofungi with medicinal properties is very short in comparison to the number of saprobics, though there is some indication that they have been studied less because they cannot be cultivated (Reshetnikov et al. 2001). Out of the 182 medicinal fungi reported by the FAO (2004), only $5 \%$ are ectomycorrhizal. This is probably an underestimate for the ectomycorrhizal species (Mao 2000) since research efforts have concentrated on saprobic species that can be cultivated, thus providing a guaranteed supply and uniformity of product.

Mushrooms used in traditional medicine are known as medicinal mushrooms (Ejelonu et al. 2013). They produce medically significant metabolites or, nowadays, can be induced to produce such metabolites using biotechnology. Medicinal mushrooms 
Table 2.3 Important genera of wild fungi with notes on uses and trade (FAO 2004).

\begin{tabular}{|c|c|c|}
\hline Genus & $\begin{array}{l}\text { No. of } \\
\text { species, use } \\
\text { and } \\
\text { properties }\end{array}$ & Country use and general notes \\
\hline Agaricus & $\begin{array}{l}\mathbf{6 0} \\
\text { Food } 43 \\
\text { Edible } 17 \\
\text { Medicinal } 6\end{array}$ & $\begin{array}{l}\text { Edible species reported from } 29 \text { countries, as food in } 13 \\
\text { (underreported, though note possible confusion between wild } \\
\text { and cultivated origins). Agaricus species are regularly collected } \\
\text { from the wild but only cultivated forms are exported. Some } \\
\text { species are poisonous. A. bisporus (J.E. Lange) Emil J. Imbach is } \\
\text { the most commonly cultivated edible fungus. The medicinal } \\
\text { A. blazei Murrill (1945) ss. Heinem. is exported from Brazil to } \\
\text { Japan and cultivated and sold in China }\end{array}$ \\
\hline Amanita & $\begin{array}{l}\mathbf{8 3} \\
\text { Food } 42 \\
\text { Edible } 39 \\
\text { Medicinal } 7\end{array}$ & $\begin{array}{l}\text { Edible species reported from } 31 \text { countries; as food in } 15 \\
\text { (underreported). Amanita caesarea (Scop.) Pers. is highly } \\
\text { valued in Mexico, Turkey, and Nepal. Few species are traded } \\
\text { across national borders. There are a notable number of } \\
\text { poisonous species. Amanita phalloides (Vaill. ex Fr.) Link is a } \\
\text { major cause of deaths around the world from consumption of } \\
\text { wild fungi }\end{array}$ \\
\hline Auricularia & $\begin{array}{l}\mathbf{1 3} \\
\text { Food } 10 \\
\text { Edible } 3 \\
\text { Medicinal } 4\end{array}$ & $\begin{array}{l}\text { Edible species reported from } 24 \text { countries, as food in } 10 \\
\text { (underreported). A global genus with a relatively small number of } \\
\text { species. Known generically as "ear fungi," they are distinctive, } \\
\text { easily recognized and consumed by forest dwellers in Kalimantan } \\
\text { as well as rural communities in all continents. Some species have } \\
\text { medicinal properties. There is a major trade in cultivated species } \\
\text { though few data have been seen. Key species: A. auricula-judae } \\
\text { (Bull.) J. Schröt. }\end{array}$ \\
\hline Boletus & $\begin{array}{l}72 \\
\text { Food } 39 \\
\text { Edible } 33 \\
\text { Medicinal } 7\end{array}$ & $\begin{array}{l}\text { Edible species reported from } 30 \text { countries; as food in } 15 \\
\text { (underreported). Boletus edulis Bull. is the best known } \\
\text { species, regularly collected and sold, and a major export from } \\
\text { outside and within Europe. There are some poisonous species } \\
\text { but few incidents. "Bolete" is a general description of a } \\
\text { macrofungus with a stalk and pores on the underside of the } \\
\text { cap. Apprehension exists about eating "boletes" in east and } \\
\text { southern Africa }\end{array}$ \\
\hline Cantharellus & $\begin{array}{l}42 \\
\text { Food 22 } \\
\text { Edible 20 } \\
\text { Medicinal } 3\end{array}$ & $\begin{array}{l}\text { Edible species reported from } 45 \text { countries; as food in } 22 \\
\text { (underreported). A diverse and cosmopolitan genus containing } \\
\text { widespread species such as C. cibarius Fr. Sold in markets in } \\
\text { many countries, sometimes in functional mixtures of different } \\
\text { species. Major quantities are collected and exported around the } \\
\text { world. No poisonous species }\end{array}$ \\
\hline Cordyceps & $\begin{array}{l}37 \\
\text { Edible ?35 } \\
\text { Medicinal } 9\end{array}$ & $\begin{array}{l}\text { Useful species (mostly medicinal) reported from three } \\
\text { countries. } \\
\text { The only reason for eating species is for health benefits. Collected } \\
\text { intensively in parts of China and less so in Nepal. Many species } \\
\text { described from Japan, but local use uncertain. Widely valued for } \\
\text { its medicinal properties and an important source of income for } \\
\text { collectors. Key species: probably C. sinensis (Berk.) Sacc.and } \\
\text { C. militaris (L.) Fr. }\end{array}$ \\
\hline
\end{tabular}


Table 2.3 (Continued)

\begin{tabular}{|c|c|c|}
\hline Genus & $\begin{array}{l}\text { No. of } \\
\text { species, use } \\
\text { and } \\
\text { properties }\end{array}$ & Country use and general notes \\
\hline Cortinarius & $\begin{array}{l}50 \\
\text { Food } 30 \\
\text { Edible } 20 \\
\text { Medicinal } \\
10\end{array}$ & $\begin{array}{l}\text { Edible species reported from } 11 \text { countries; as food in three. } \\
\text { Widely disregarded in Europe and North America because of } \\
\text { concern about poisonous species. Most records of local use are } \\
\text { restricted to a few countries, e.g. China, Japan, the Russian } \\
\text { Federation, and Ukraine. No known export trade }\end{array}$ \\
\hline Laccaria & $\begin{array}{l}\mathbf{1 4} \\
\text { Food } 9 \\
\text { Edible } 5 \\
\text { Medicinal } 4\end{array}$ & $\begin{array}{l}\text { Edible species reported from } 17 \text { countries; as food in four } \\
\text { (underreported). Regularly collected and eaten, also sold widely } \\
\text { in markets. No reports of export trade, which is unsurprising } \\
\text { given their generally small size and unremarkable taste. Key } \\
\text { species is L. laccata (Scop.) Cooke }\end{array}$ \\
\hline Lactarius & $\begin{array}{l}94 \\
\text { Food } 56 \\
\text { Edible } 38 \\
\text { Medicinal } 7\end{array}$ & $\begin{array}{l}\text { Edible species reported from } 39 \text { countries; as food in } 17 \\
\text { (underreported). Many different species are regularly collected } \\
\text { and eaten. Key species such as } L \text {. deliciosus (L. ex Fr.) S.F. Gray are } \\
\text { highly esteemed and there is a valuable trade in Europe. Several } \\
\text { key species frequently sold in local markets. Little reported } \\
\text { export activity despite widespread popularity, perhaps reflecting } \\
\text { the diversity of species on offer }\end{array}$ \\
\hline Leccinum & $\begin{array}{l}22 \\
\text { Food } 4 \\
\text { Edible } 9\end{array}$ & $\begin{array}{l}\text { Edible species reported from eight countries; as food in two. } \\
\text { Widely eaten and collected but little trade beyond national } \\
\text { boundaries. Key species L. scabrum (Bull.) Gray. Possible } \\
\text { exports from pine plantations in tropics, but poorly } \\
\text { understood }\end{array}$ \\
\hline Lentinula & $\begin{array}{l}3 \\
\text { Food } 2 \\
\text { Edible } 1 \\
\text { Medicinal } 1\end{array}$ & $\begin{array}{l}\text { Edible species reported from six countries; as food in four. } \\
\text { Lentinula edodes (Berk.) Pegler is the key species (= Lentinus } \\
\text { edodes). Known as shiitake, it is cultivated in many countries and } \\
\text { is an important commercial species (nearing } 30 \% \text { cultivated } \\
\text { amount). Cultivated shiitake is exported }\end{array}$ \\
\hline Lentinus & $\begin{array}{l}\mathbf{2 8} \\
\text { Food } 16 \\
\text { Edible } 12 \\
\text { Medicinal } 5\end{array}$ & $\begin{array}{l}\text { Edible species reported from } 24 \text { countries; as food in eight } \\
\text { (underreported). Although many different species are collected } \\
\text { and used locally, only two or three are of any significance. Key } \\
\text { species probably L. tuber-regium (Fr.) Fr., valued for its medicinal } \\
\text { properties. Little or no no export trade }\end{array}$ \\
\hline Lycoperdon & $\begin{array}{l}22 \\
\text { Food } 9 \\
\text { Edible } 10 \\
\text { Medicinal } \\
10\end{array}$ & $\begin{array}{l}\text { Edible species reported from } 19 \text { countries; as food in seven } \\
\text { (underreported).There are many records of species being eaten } \\
\text { but typically reports are of small-scale collecting and use. Only } \\
\text { market sales known are in Mexico. Key species are L. pyriforme } \\
\text { Schaeff. and L. perlatum Pers. }\end{array}$ \\
\hline Macrolepiota & $\begin{array}{l}13 \\
\text { Food } 7 \\
\text { Edible } 6 \\
\text { Medicinal } 1\end{array}$ & $\begin{array}{l}\text { Edible species reported from } 33 \text { countries; as food in nine } \\
\text { (underreported). Macrolepiota procera (Scop.) Singer is the key } \\
\text { species and most recorded, from around } 15 \text { countries on all } \\
\text { major continents. Locally consumed; trade is essentially small- } \\
\text { scale and local }\end{array}$ \\
\hline
\end{tabular}




\begin{tabular}{|c|c|c|}
\hline Genus & $\begin{array}{l}\text { No. of } \\
\text { species, use } \\
\text { and } \\
\text { properties }\end{array}$ & Country use and general notes \\
\hline Morchella & $\begin{array}{l}\mathbf{1 8} \\
\text { Food } 14 \\
\text { Edible } 4 \\
\text { Medicinal } 5\end{array}$ & $\begin{array}{l}\text { Edible species reported from } 28 \text { countries; as food in } 10 \\
\text { (underreported). Highly valued genus with several species } \\
\text { that fruit in abundance in certain years and are a major source } \\
\text { of (export) revenue in several countries. Species are not always } \\
\text { eaten in countries where they are collected. Key species } \\
\text { M. esculenta Fr. }\end{array}$ \\
\hline Pleurotus & $\begin{array}{l}\mathbf{4 0} \\
\text { Food } 22 \\
\text { Edible } 18 \\
\text { Medicinal } 7\end{array}$ & $\begin{array}{l}\text { Edible species reported from } 35 \text { countries; as food in } 19 \\
\text { (underreported). Key species is P. ostreatus (Jacq. ex Fr.) } \\
\text { P. Kumm. in terms of amounts eaten, predominantly from } \\
\text { cultivation. Other species said to be tastier. Species occur } \\
\text { widely and are regularly picked though seldom traded } \\
\text { from the wild }\end{array}$ \\
\hline Polyporus & $\begin{array}{l}30 \\
\text { Food } 15 \\
\text { Edible } 9 \\
\text { Medicinal } \\
12\end{array}$ & $\begin{array}{l}\text { Edible and medicinal species reported from } 20 \text { countries; as food } \\
\text { or medicine in seven. Many species are regularly used and eaten } \\
\text { but of relatively minor importance. Some are cultivated. Only one } \\
\text { record known, from Nepal, of selling in markets. No international } \\
\text { trade is known to occur }\end{array}$ \\
\hline Ramaria & $\begin{array}{l}44 \\
\text { Food } 33 \\
\text { Edible } 11 \\
\text { Medicinal } 5\end{array}$ & $\begin{array}{l}\text { Edible species reported from } 18 \text { countries; used as food in seven. } \\
\text { Many records of local use. Regularly sold in markets in Nepal and } \\
\text { Mexico and elsewhere. Several major species but perhaps } \\
R \text {. botrytis (Pers.) Ricken is the most commonly collected and } \\
\text { used. Some species are poisonous; others are reported to have } \\
\text { medicinal properties }\end{array}$ \\
\hline Russula & $\begin{array}{l}128 \\
\text { Food } 71 \\
\text { Edible } 54 \\
\text { Medicinal } \\
25\end{array}$ & $\begin{array}{l}\text { Edible species reported from } 28 \text { countries; as food in } 12 \\
\text { (underreported). One of the most widespread and commonly } \\
\text { eaten genera containing many edible species. Also poisonous } \\
\text { varieties though most can be eaten after cooking. Regularly sold } \\
\text { in markets but species names not always recorded. Genus is of } \\
\text { tropical origin. Notable species include } R \text {. delica Fr. and } \\
R \text {. virescens (Schaeff.) Fr. }\end{array}$ \\
\hline Suillus & $\begin{array}{l}27 \\
\text { Food } 26 \\
\text { Edible } 1 \\
\text { Medicinal } 2\end{array}$ & $\begin{array}{l}\text { Edible species reported from } 25 \text { countries; as food in } 10 \\
\text { (underreported). Key species is S. luteus, exported from Chile. } \\
\text { Suillus granulatus (L.) Roussel is more widely recorded } \\
\text { though its use as a food is limited. Many other species are } \\
\text { regularly collected and eaten and several are sold in } \\
\text { Mexican markets }\end{array}$ \\
\hline Terfezia & $\begin{array}{l}7 \\
\text { Food } 5 \\
\text { Edible } 2\end{array}$ & $\begin{array}{l}\text { Edible species reported from eight countries; as food in four. } \\
\text { Desert truffles occur widely in North Africa and parts of Asia. } \\
\text { They are said to be important but few details were found } \\
\text { concerning trade or market sales }\end{array}$ \\
\hline Termitomyces & $\begin{array}{l}27 \\
\text { Food } 23 \\
\text { Edible } 4 \\
\text { Medicinal } 3\end{array}$ & $\begin{array}{l}\text { Edible species reported from } 35 \text { countries; as food in } 16 \\
\text { (underreported). Highly esteemed genus. Many species are widely } \\
\text { eaten with often high nutritional value. Collected notably } \\
\text { throughout Africa. Used widely in Asia but less well documented. } \\
\text { Notable species include T. clypeatus R. Heim, T. microporus } \\
\text { R. Heim and T. striatus (Beeli) R. Heim. Sold in markets and } \\
\text { along roadsides, and good source of income }\end{array}$ \\
\hline
\end{tabular}


Table 2.3 (Continued)

\begin{tabular}{|c|c|c|}
\hline Genus & $\begin{array}{l}\text { No. of } \\
\text { species, use } \\
\text { and } \\
\text { properties }\end{array}$ & Country use and general notes \\
\hline Tricholoma & $\begin{array}{l}52 \\
\text { Food } 39 \\
\text { Edible } 13 \\
\text { Medicinal } \\
17\end{array}$ & $\begin{array}{l}\text { Edible species reported from } 30 \text { countries; as food in } 11 \\
\text { (underreported). The most important species is T. matsutake (Ito } \\
\text { et Imai) Sing., in terms of volume collected and financial value. } \\
\text { China, both Koreas and the Russian Federation are major } \\
\text { exporters to Japan. The Pacific northwest of North America, } \\
\text { Morocco and Mexico export related species, but only in } \\
\text { significant quantities from the first. Some species are poisonous if } \\
\text { eaten raw; others remain so even after cooking. Ignored or poorly } \\
\text { regarded in several countries prior to export opportunities, e.g. } \\
\text { Bhutan, Mexico (Oaxaca) }\end{array}$ \\
\hline $\begin{array}{l}\text { Tuber } \\
\text { (truffles) }\end{array}$ & $\begin{array}{l}18 \\
\text { Food } 8 \\
\text { Edible } 10\end{array}$ & $\begin{array}{l}\text { Edible species reported from eight countries; as food in four } \\
\text { (underreported). Contains species of extremely high value and } \\
\text { much esteemed in gourmet cooking, but only of very minor } \\
\text { significance to poor communities in the south. There is some } \\
\text { interest from Turkey in management of truffles. Scientific } \\
\text { principles have been applied to truffle management and } \\
\text { successful schemes initiated in Italy, France, Spain, and New } \\
\text { Zealand. The "false truffles" comprise other genera, e.g. } \\
\text { Tirmania, Rhizopogon, Terfezia }\end{array}$ \\
\hline Volvariella & $\begin{array}{l}\mathbf{1 2} \\
\text { Food } 5 \\
\text { Edible } 7 \\
\text { Medicinal } 1\end{array}$ & $\begin{array}{l}\text { Edible species reported from } 27 \text { countries; as food in } 7 \\
\text { (underreported, though note possible confusion between wild } \\
\text { and cultivated origins). Key species is V. volvacea (Bul. ex Fr.) } \\
\text { Singer. Widely cultivated and sold in local markets but also } \\
\text { collected from the wild }\end{array}$ \\
\hline
\end{tabular}

Information obtained mostly from developing countries. "Food" signifies confirmed use of species; "edible" is a noted property without confirmed consumption. The total number of edible species is the sum of the two. Use refers to country of origin and not countries of export. "Medicinal" confirms use of species for medicinal reasons. Edible species may have medicinal properties and therefore the total number of species in bold may be less than the sum of individual uses. See Lincoff (2002) for distribution of major groups of edible fungi around the world (FAO 2004).

are attracting greater scientific and commercial interest, prompted by a renewed awareness of the use of such material in traditional Chinese medicine (FAO 2004). Edible mushrooms are consumed by humans for their nutritional value and they are also consumed for their presumed medicinal value or, more recently, as functional food for their nutraceutical properties. The medicinal properties of mushrooms depend on several bioactive compounds and their bioactivity depends on how the mushrooms are prepared and eaten. Mushrooms represent a vast source of yet undiscovered potent pharmaceutical products (FAO 2009). The International Journal of Medicinal Mushrooms began publication in 1999 and is an important source of information for this expanding field of research (Wasser \& Weis 1999a,b).

There has been a spectacular increase of interest and commercial activity concerned with dietary supplements, functional foods, and other products that are 


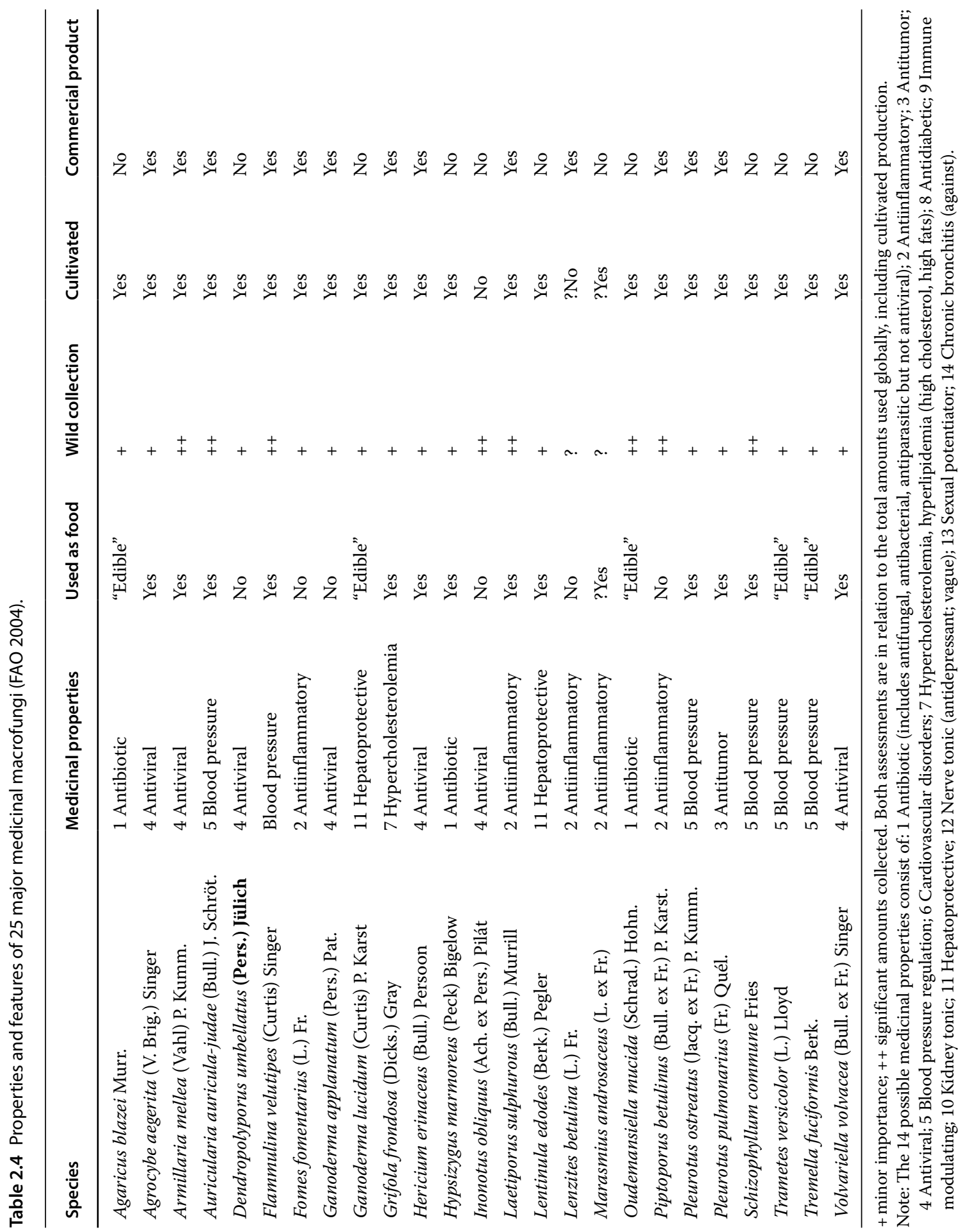


"more than just food" (Etkin \& Johns 1998; Wasser et al. 2000). Mushrooms are increasingly appreciated for their nutritional (Kalac 2009, 2012, 2013) and nutraceutical properties. In addition to culinary and nutritional value, being a food with little fat and very healthy, many research studies demonstrate the benefits that some varieties provide in the human body, strengthening the immune system and fighting diseases like cancer, HIV virus, etc. (includes A. blazei, L. edodes, G. lucidum). Moreover, they are also used for the production of antibiotics and biocontrol of viruses (Anguix 2011).

Beyond nutritional characteristics, mushrooms have also been extensively studied for their medicinal properties, mainly due to their richness in bioactive compounds that present antioxidant, anticancer. and antimicrobial properties, among other bioactivities (Alves et al. 2012; Fernandes et al. 2015; Ferreira et al. 2009. 2010; Heleno et al. 2015); for more information see Chapter 4 . Although these new products have clear economic potential, their relevance to developing countries is at present still marginal but potentially increasing. Thus per capita value resulting from this production is expected to increase in the medium term (Anguix 2011).

Also noteworthy is the use of certain fungi for bioremediation: soil decontamination, affected by oil spills, as well as biological control of nematodes and insects (Anguix 2011).

Ceremonial and religious roles played by wild fungi in different cultures are closely associated with hallucinogenic properties. Hallucinogenic mushrooms (e.g. psilocybin mushrooms) are occasionally consumed for recreational or religious purposes, but can produce severe nausea and disorientation, and are therefore not commonly considered edible although they are not poisonous. This has attracted much scientific interest (FAO 2004) and analytical work has been carried out to characterize the chemical compounds responsible for the hallucinogenic effects. Alternative uses for those compounds have also been under study.

\subsection{Cultivation of Edible Fungi}

Edible mushrooms include many fungal species that are either harvested from the wild or cultivated. Easily cultivatable and common wild mushrooms are often available in markets.

Mushroom cultivation started in a very rudimentary manner in Asia about 1000 years ago, where the shiitake was collected in times of mild climate. Subsequently, many attempts were made to grow mushrooms, with uncertain results due to the almost total ignorance of the necessary requirements. In Europe, mushroom cultivation emerged ca. 300 years ago in caves in the area of Paris and later spread to other countries such as Germany, Hungary, etc. (Anguix 2011). It was not until the second half of the twentieth century that a fundamental transformation occurred at all levels to develop the cultivation of mushrooms.

- Selective substrates for growing mushrooms were developed from agricultural and forestry residues, giving rise to regular production.

- A method of growing mycelium was created with selection of the best suited for cultivation. 
- Modern facilities arose where environmental conditions in each of the phases of fungal development were controlled.

- The grower learned and professionalized relevant cultivation techniques.

- A specialized market of fungi with different presentations increased consumption.

- A diversification of fungi and the cultivation of "exotic" fungi occurred.

- As in other sectors of agriculture, mechanization allowed for more consistent production and decreased the need for labor (Anguix 2011).

Within saprobic fungi, two main subgroups exist.

- Primary degraders are those with the ability to initiate the degradation of organic matter.

- Secondary degraders are those that can only synthesize simple substances, generally degraded by the primary degraders. These two subgroups contain the cultivated mushrooms that include some 40 edible species suitable for human consumption, 20 of them exploited industrially but only about six or seven with real commercial importance (Anguix 2011).

There are almost 100 species of saprobic fungi that can be cultivated (Table 2.5). Agaricus bisporus (J.E.Lange) Emil J. Imbach, L. edodes, and Pleurotus spp. dominate commercial markets and account for almost three-quarters of the cultivated mushrooms grown around the world (Chang 1999). The culture of mushrooms offers economic opportunities as well as nutritional and health benefits (Mshigeni \& Chang 2000). The main species cultured are grown on a variety of organic substrates, including waste from the production of cotton and coffee. The technologies are well established and successful mushroom industries have been established in many countries. There has been a huge increase in production over the past decade, especially following increased capacity in China. The cultivation of straw mushrooms ( $V$. volvacea) is integrated with rice production in Vietnam. Wherever saprobic species are cultivated, they require a steady supply of raw materials (Pauli 1998).

The number of saprophytic cultivated species is steadily increasing, and advice and practical information are readily available (Stamets 2000). The annual global trade in cultivated, saprobic species in 1999 was estimated at US\$18 billion (FAO 2004). The economic importance of edible fungi saprobes is not negligible. Species such as button mushroom (A. bisporus), oyster mushroom (P. ostreatus), king oyster mushroom (Pleurotus eryngii (DC.) Quél.) and shiitake (L. edodes) are appreciated for their gastronomic quality, and are among the most consumed and marketed. The industrial cultivation of edible fungi saprobes has been achieved with numerous species after the necessary control of environmental conditions such as temperature, humidity, ventilation, and photoperiod, with different needs depending on the species (Fernández-Toirán et al. 2011a).

Ectomycorrhizal fungi can also be "cultivated." Trees are inoculated with truffle fungus that then infect the roots and form the ectomycorrhiza. The trees are carefully tended to encourage production of truffles. Methods of "culturing" truffles are constantly being improved (Hall et al. 1998).

Table 2.5 lists the 92 names prepared from Stamets (2000) and Chang and Mao (1995). This list contains only saprobic species and excludes ectomycorrhizal species such as truffles (Tuber spp.) that are managed in natural habitats. 
Table 2.5 Edible and medicinal fungi that can be cultivated (FAO 2004).

\begin{tabular}{|c|c|c|}
\hline Agaricus arvenses Schaeff. & Hericium coralloides Scop. & $\begin{array}{l}\text { Paneolus subalteatus } \\
\text { (Berk. \& Broome) Sacc. }\end{array}$ \\
\hline Agaricus augustus Fr. & Hericium erinaceum (Bull.) Persoon & Paneolus tropicalis Ola'h \\
\hline $\begin{array}{l}\text { Agaricus bisporus (J.E. } \\
\text { Lange) Emil J. Imbach }\end{array}$ & Hypholoma capnoides (Bull.) Persoon & Phallus impudicus L. \\
\hline $\begin{array}{l}\text { Agaricus bitorquis (Quélet) } \\
\text { Sacc. }\end{array}$ & $\begin{array}{l}\text { Hypholoma sublateritium (Schaeff.) } \\
\text { P. Kumm. }\end{array}$ & Phellinus spp. \\
\hline Agaricus blazei Murrill & $\begin{array}{l}\text { Hypsizygus marmoreus (Peck) } \\
\text { Bigelow }\end{array}$ & $\begin{array}{l}\text { Pholiota nameko (T. Itô) } \\
\text { S. Ito \& S. Imai }\end{array}$ \\
\hline Agaricus brunnescens Peck & $\begin{array}{l}\text { Hypsizygus tessulatus (Bull. ex Fr.) } \\
\text { Singer }\end{array}$ & $\begin{array}{l}\text { Piptoporus betulinus } \\
\text { (Bull. ex Fr.) P. Karst. }\end{array}$ \\
\hline Agaricus campestris L. & lnonotus obliquus (Ach. ex Pers.) Pilát & Piptoporus indigenus \\
\hline Agaricus subrufescens Peck. & $\begin{array}{l}\text { Kuehneromyces mutabilis (Schaeff.) } \\
\text { Singer \& A.H. Sm. }\end{array}$ & $\begin{array}{l}\text { Pleurocybella porrigens } \\
\text { (Pers.) Singer }\end{array}$ \\
\hline $\begin{array}{l}\text { Agrocybe aegerita } \\
\text { (V. Brig.) Singer }\end{array}$ & Laetiporus sulphureus (Bull.) Murrill & $\begin{array}{l}\text { Pleurotus citrinopileatus } \\
\text { Singer }\end{array}$ \\
\hline $\begin{array}{l}\text { Agrocybe cylindracea (DC.) } \\
\text { Maire }\end{array}$ & $\begin{array}{l}\text { Laricifomes officinalis (Vill.) Kotl. \& } \\
\text { Pouzar }\end{array}$ & $\begin{array}{l}\text { Pleurotus cornucopiae } \\
\text { (Paulet) Rolland }\end{array}$ \\
\hline $\begin{array}{l}\text { Agrocybe molesta (Lasch) } \\
\text { Singer }\end{array}$ & Lentinula edodes (Berk.) Pegler & $\begin{array}{l}\text { Pleurotus cystidiosus } \\
\text { Luis }\end{array}$ \\
\hline $\begin{array}{l}\text { Agrocybe praecox (Pers.) } \\
\text { Fayod }\end{array}$ & Lentinus strigosus Fr. & $\begin{array}{l}\text { Pleurotus djamour } \\
\text { (Rumph. ex Fr.) Boedijn }\end{array}$ \\
\hline Albatrellus spp. & Lentinus tigrinus (Bull.) Kühner & $\begin{array}{l}\text { Pleurotus eryngii (DC.) } \\
\text { Quél. }\end{array}$ \\
\hline Armillaria mellea & $\begin{array}{l}\text { Lentinus tuber-regium (Rumph. ex } \\
\text { Fr.) Singer }\end{array}$ & $\begin{array}{l}\text { Pleurotus euosmus } \\
\text { (Berk.) Sacc }\end{array}$ \\
\hline $\begin{array}{l}\text { Auricularia auricula-judae } \\
\text { (Bull.) J. Schröt. }\end{array}$ & Lepista nuda (Bull.) Cooke & $\begin{array}{l}\text { Pleurotus ostreatus } \\
\text { (Jacq. ex Fr.) P. Kumm }\end{array}$ \\
\hline $\begin{array}{l}\text { Auricularia fuscosuccinea } \\
\text { (Mont.) Henn. }\end{array}$ & Lepista sordida (Schumach.) Singer & $\begin{array}{l}\text { Pleurotus pulmonarius } \\
\text { (Fr.) Quél. }\end{array}$ \\
\hline $\begin{array}{l}\text { Auricularia polytricha } \\
\text { (Mont.) Sacc. }\end{array}$ & $\begin{array}{l}\text { Lyophyllum fumosum (Pers. Fr.) PD } \\
\text { Orton }\end{array}$ & $\begin{array}{l}\text { Pleurotus rhodophyllus } \\
\text { Bres }\end{array}$ \\
\hline $\begin{array}{l}\text { Calvatia gigantea (Batsch } \\
\text { ex Pers.) Lloyd }\end{array}$ & $\begin{array}{l}\text { Lyophyllum ulmarium (Bull.) Kühner } \\
\text { (= Hypsizygus ulmarium (Bull.) } \\
\text { Redhead) }\end{array}$ & $\begin{array}{l}\text { Pluteus cervinus } \\
\text { (Schäffer: Fr) P. Kumm. }\end{array}$ \\
\hline $\begin{array}{l}\text { Coprinus comatus (O.F. } \\
\text { Müll.) Pers. }\end{array}$ & $\begin{array}{l}\text { Macrocybe gigantea (Massee) Pegler \& } \\
\text { Lodge (= Tricholoma giganteum } \\
\text { Massee) }\end{array}$ & Polyporus indigenus \\
\hline $\begin{array}{l}\text { Daedalea quercina (L.) } \\
\text { Pers. }\end{array}$ & Macrolepiota procera (Scop.) Singer & Polyporus saporema \\
\hline $\begin{array}{l}\text { Dictyophora duplicata } \\
\text { (Bosc) E. Fisch. }\end{array}$ & Marasmius oreades (Bolton) Fr. & $\begin{array}{l}\text { Polyporus umbellatus } \\
\text { (Pers.) Fr. }\end{array}$ \\
\hline $\begin{array}{l}\text { Flammulina velutipes } \\
\text { (Curtis) Singer }\end{array}$ & Morchella angusticeps Peck & $\begin{array}{l}\text { Dendropolyporus } \\
\text { umbellatus (Pers.) Jülich }\end{array}$ \\
\hline
\end{tabular}


Table 2.5 (Continued)

\begin{tabular}{|c|c|c|}
\hline Fomes fomentarius (L.) Fr. & Morchella esculenta Fr. & $\begin{array}{l}\text { Psilocybe cyanescens } \\
\text { Wakefield }\end{array}$ \\
\hline $\begin{array}{l}\text { Ganoderma applanatum } \\
\text { (Pers.) Pat. }\end{array}$ & $\begin{array}{l}\text { Neolentinus lepideus (Fr.) } \\
\text { Redhead \& Ginns } \\
\text { (= Lentinus lepidus) }\end{array}$ & $\begin{array}{l}\text { Schizophyllum commune } \\
\text { Fries }\end{array}$ \\
\hline $\begin{array}{l}\text { Ganoderma curtisii (Berk.) } \\
\text { Murrill }\end{array}$ & Oligoporus spp. & $\begin{array}{l}\text { Stropharia } \\
\text { rugusoannulatav } \\
\text { Wakefield }\end{array}$ \\
\hline $\begin{array}{l}\text { Ganoderma lucidum } \\
\text { (Curtis) P. Karst }\end{array}$ & - & $\begin{array}{l}\text { Trametes cinnabarinum } \\
\text { (Jacq.) Fr. }\end{array}$ \\
\hline $\begin{array}{l}\text { Ganoderma oregonense } \\
\text { Murr. }\end{array}$ & $\begin{array}{l}\text { Oudemansiella radicata (Relh. ex Fr.) } \\
\text { Sing. }\end{array}$ & $\begin{array}{l}\text { Trametes versicolor }(\mathrm{L} .) \\
\text { Lloyd }\end{array}$ \\
\hline $\begin{array}{l}\text { Ganoderma sinense J.D. } \\
\text { Zhao, L.W. Hsu \& X.Q. } \\
\text { Zhang }\end{array}$ & Oxyporus nobilissimus W.B.Cooke & $\begin{array}{l}\text { Tremella fuciformis } \\
\text { Berk. }\end{array}$ \\
\hline $\begin{array}{l}\text { Ganoderma tenue J.D. } \\
\text { Zhao, L.W. Hsu \& X.Q. } \\
\text { Zhang }\end{array}$ & $\begin{array}{l}\text { Panellus serotinus (Pers.) Kühner } \\
\text { (= Hohenbuehelia serotina (Pers.) } \\
\text { Singer) }\end{array}$ & Volvariella bombacyina \\
\hline Ganoderma tsugae Murrill & - & Volvariella volvacea \\
\hline $\begin{array}{l}\text { Grifola frondosa (Dicks.) } \\
\text { Gray }\end{array}$ & - & $\begin{array}{l}\text { Volvariella volvacea } \\
\text { gloiocephala (Fr.) Gillet }\end{array}$ \\
\hline
\end{tabular}

\subsection{Social and Economic Interest in Edible Mushrooms}

Wild useful fungi thus contribute to diet, income, and human health. Many species also play a vital ecological role through mycorrhizae, the symbiotic relationships that they form with trees. Truffles and other valuable wild edible fungi (Chantarellus, Lactarius, Boletus, Amanita, etc.) depend on trees for their growth and cannot be cultivated artificially. The mycorrhizae enable trees to grow in nutrient-poor soils. The importance of wild edible fungi continues to grow for more fundamental reasons. Legal restrictions in several countries have renewed interest in nonwood forest products (NWFP) as an alternative source of income and jobs for people previously employed in forestry. Wild edible fungi have played an important role in providing new sources of income in China, the United States of America, and many other countries (Arora 2008; FAO 2004).

Although the importance of NWFPs is recognized and accepted in Europe, forest research remains mainly focused on timber production. Consequently knowledge about European NWFPs is comparatively scarce, as is research on the ecology, management and economics required to optimize sustainable simultaneous production of different products from forests. A multidisciplinary European network on NWFPs was created in 2014 to help bridge these gaps (COST Action FP1203 2014). 


\subsection{Edible Mushroom World Production and Commercialization}

World production and commercialization of mushrooms are quite difficult to quantify. Most of the production is not officially registered and commercialization occurs in local markets without quantification.

According to FAO statistics, global mushroom production was estimated at about 3.1-7.9 million tons from 1997 to 2012 (Table 2.6), with increasing production during this 15-year period (Figure 2.3), mainly due to increases in Asia and Europe from 2007 to 2012. In the FAO database, mushrooms have been classified as FAOStat code 0449 and have been defined as including, inter alia, B. edulis, A. campestris, Morchella spp., and Tuber magnatum. Current production can be estimated to be around 7.0 million tons. Asia leads production, followed by Europe and America (see Table 2.6, Figure 2.3, Figure 2.4). Mushroom production by country shows that China, Italy, USA, The Netherlands, Poland, Spain, France, Ireland, Canada, and UK are the leading producers (Figure 2.5) (FAOStat 2015). The major mushroom-producing countries according to FAO 2012 data are China, Italy, USA, and The Netherlands, accounting for more than

Table 2.6 Mushroom and truffle production per continent (tonnes) (data from FAOStat 2015).

\begin{tabular}{lrrrr}
\hline & \multicolumn{1}{c}{1997} & \multicolumn{1}{l}{ 2002 } & \multicolumn{1}{c}{ 2007 } & \multicolumn{1}{c}{2012} \\
\hline Africa & 10846 & 10494 & 14680 & 19440 \\
Americas & 434830 & 452155 & 432890 & 470450 \\
Asia & 1618006 & 3083575 & 4347798 & 5500705 \\
Europe & 981622 & 1132332 & 1142005 & 1913007 \\
Oceania & 42985 & 51912 & 51239 & 56377 \\
World & $\mathbf{3 0 8 8 2 8 9}$ & $\mathbf{4 7 3 0 4 6 8}$ & $\mathbf{5 9 8 8 6 1 2}$ & $\mathbf{7 9 5 9 9 7 9}$ \\
\hline
\end{tabular}

All figures are aggregates and may include official, semiofficial or estimated data.

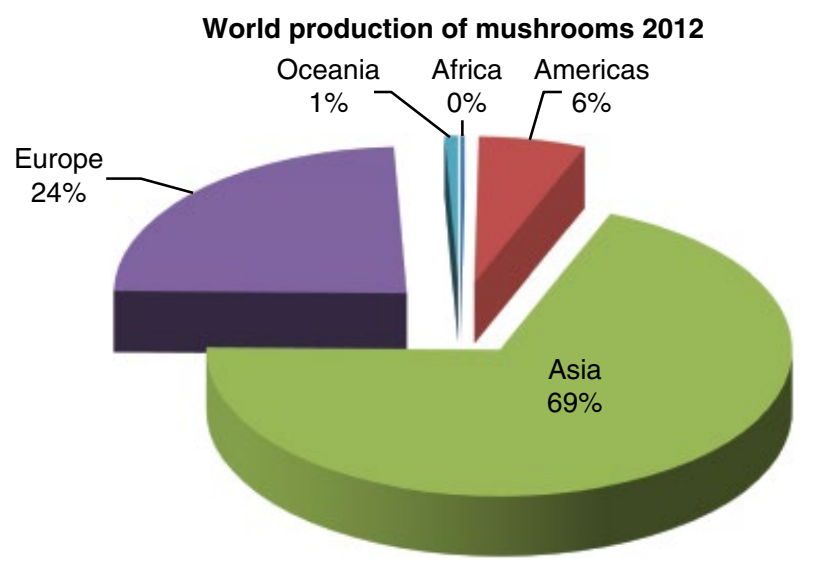

Figure 2.3 Mushroom and truffle relative production per continent (\%). Source: data from FAOStat (2015). 


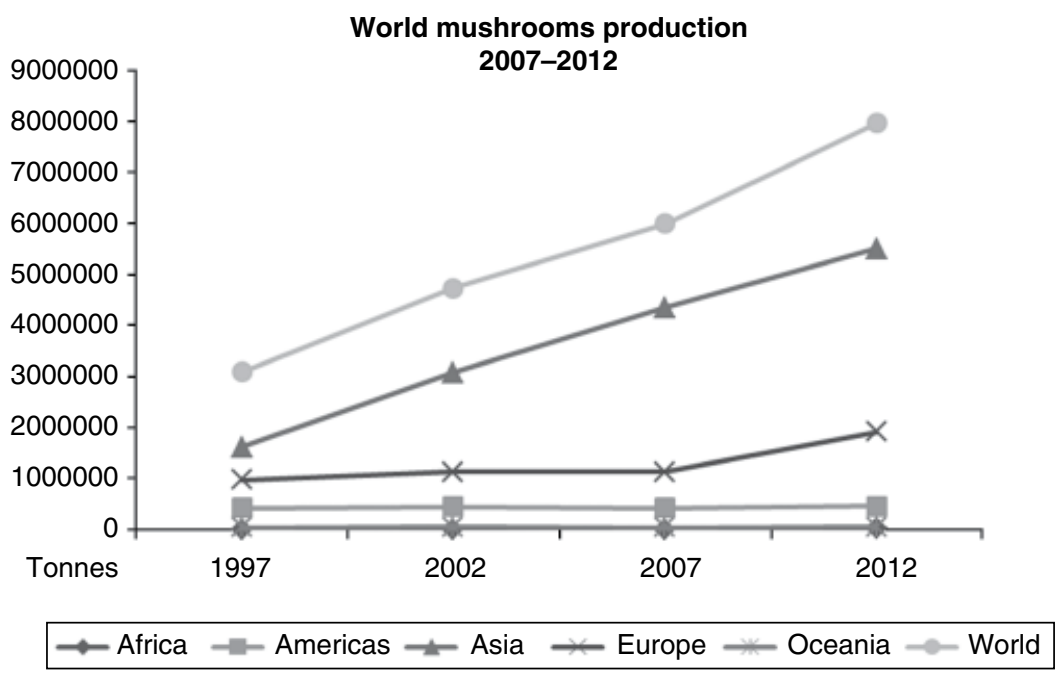

Figure 2.4 Mushroom and truffle production evolution per continent from 1997 until 2012. Source: data from FAOStat (2015).

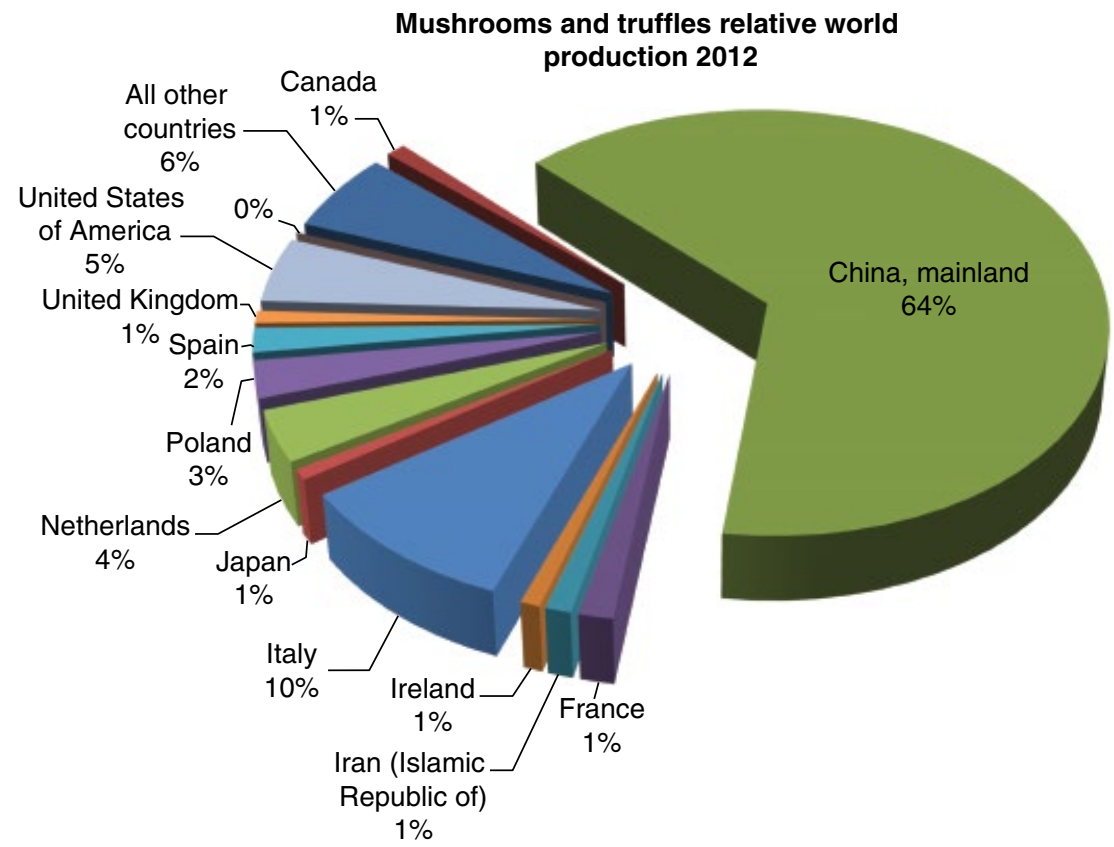

Figure 2.5 Mushroom and truffle relative production (\%) per country in 2012. Source: data from FAOStat (2015).

$80 \%$ of the world production; however, China's share alone is $64 \%$ which is more than half of the world mushroom production (see Figure 2.5, Table 2.7).

In the USA and Europe, the major contribution to mushroom production is made by the white button mushroom, A. bisporus. In Asian countries the scenario is different and other species are also cultivated for commercial production (Wakchaure 2011). 


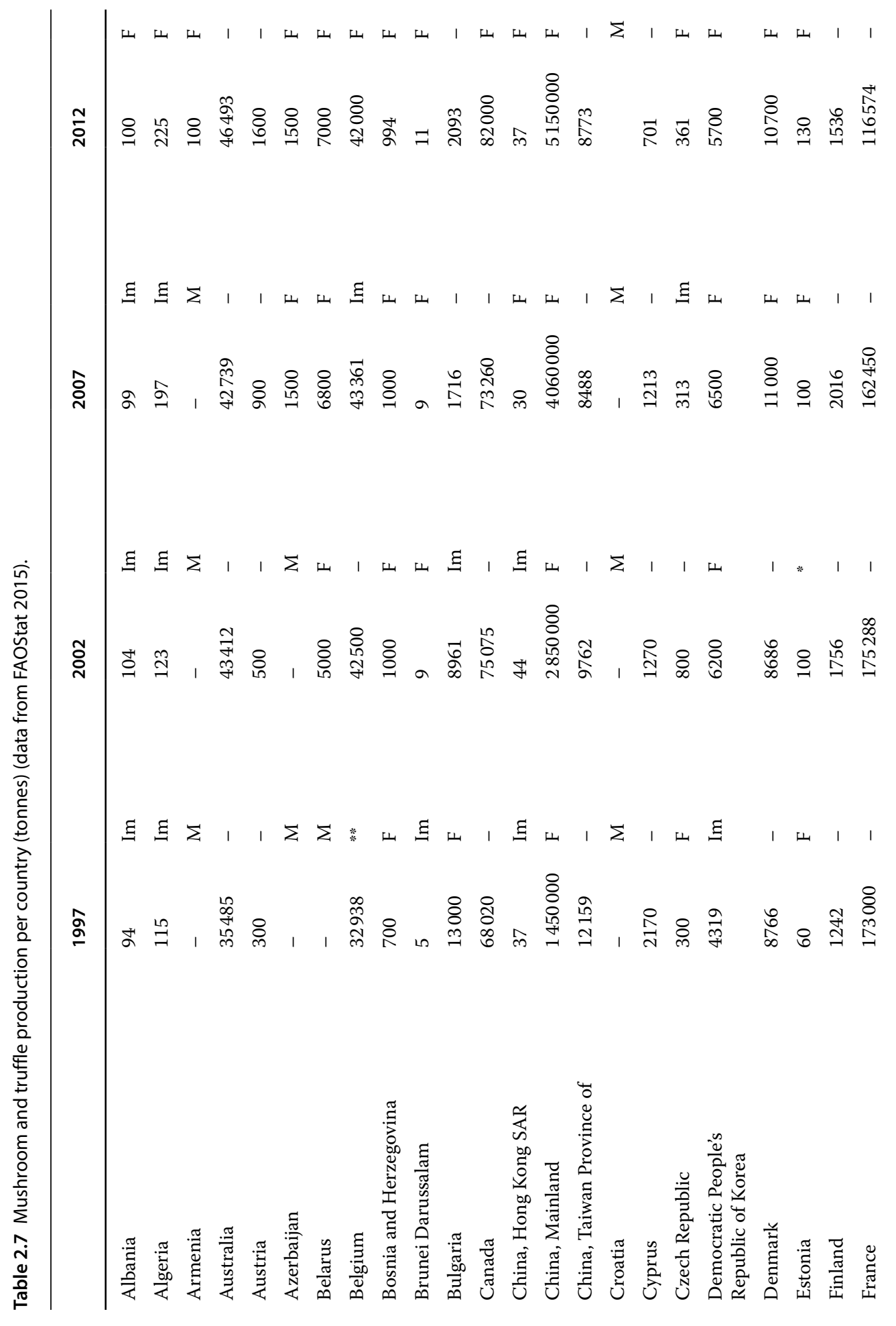




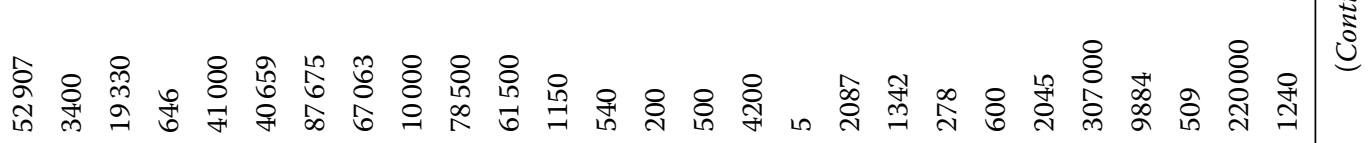

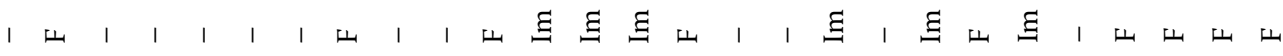

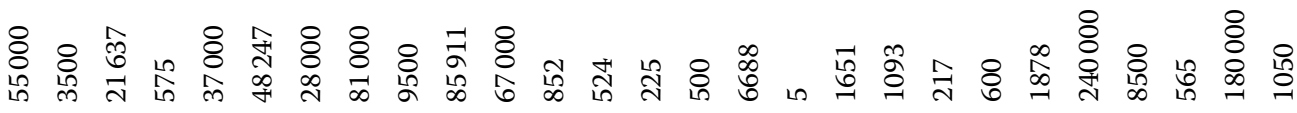

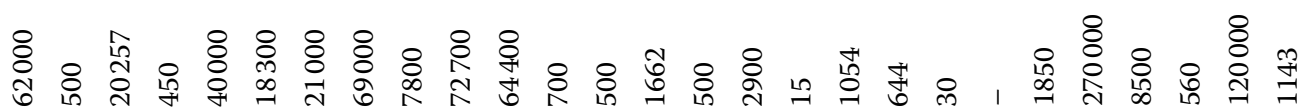

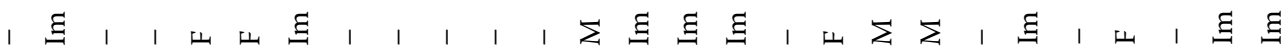

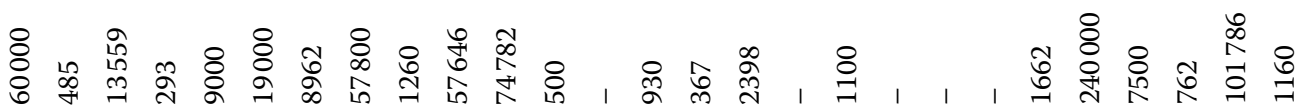

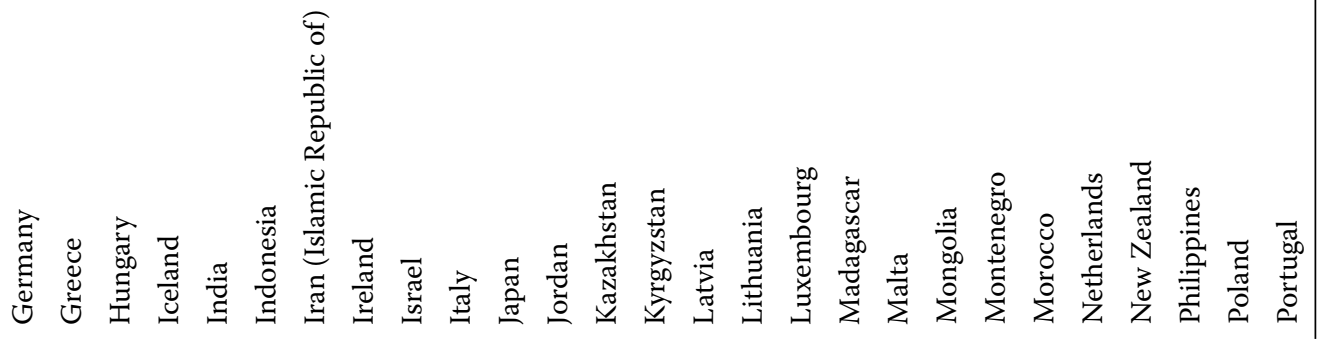




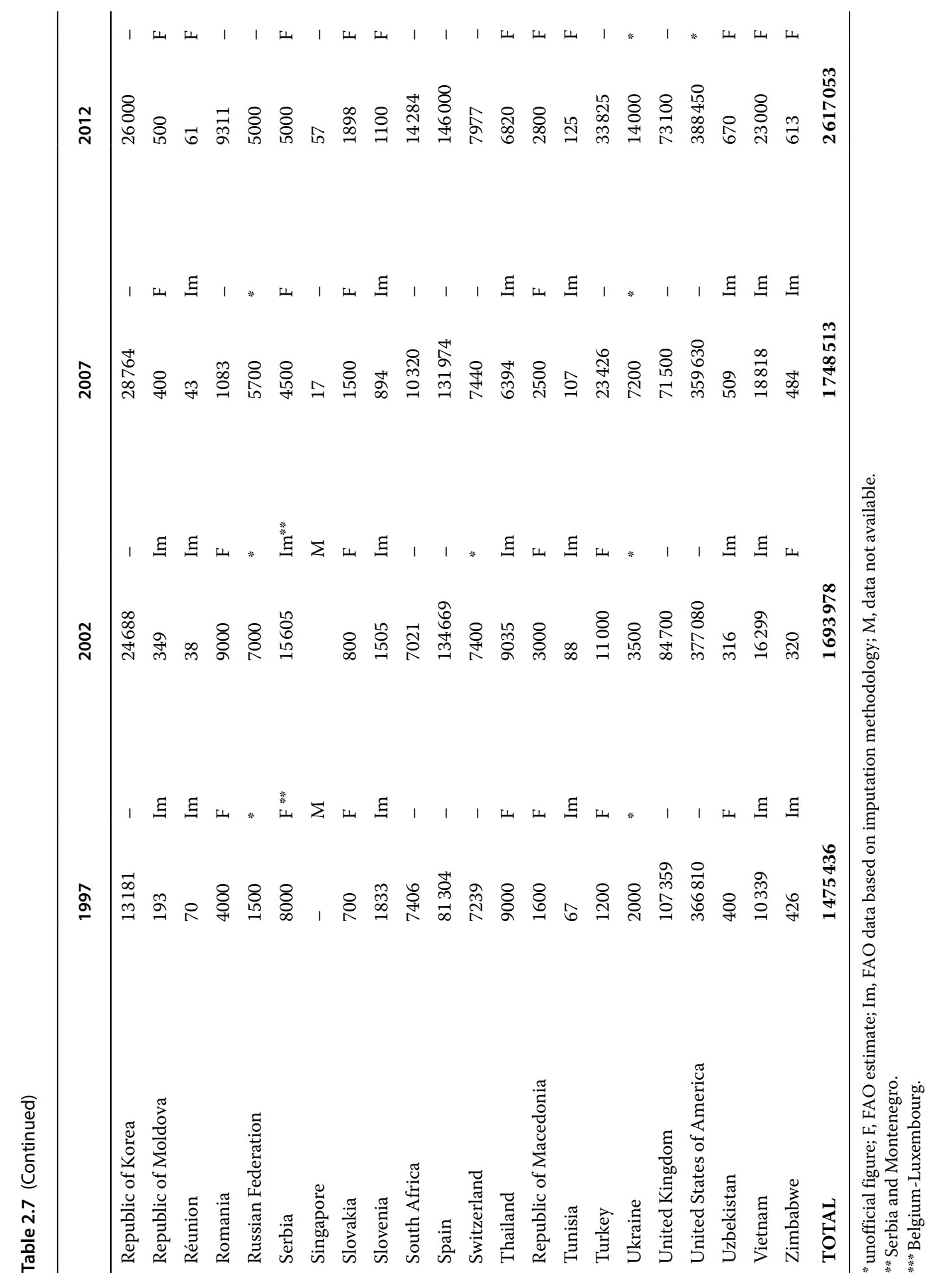


Data from the Chinese Association of Edible Fungi possibly include all these mushrooms. Consequently the mushroom production figures quoted by Chinese are at a much higher scale. This does emphasize the contribution of other edible mushrooms/ medicinal mushrooms, even if the figures may seem exaggerated. Mushroom export from China accounts for less than $5 \%$ of its total domestic production and about half of it is to Asian countries; 95\% of mushroom production in China is for local consumption, with a potential per capita value of over $10 \mathrm{~kg} /$ person/year. This is much higher than most of the European countries and the USA where it is around $3 \mathrm{~kg} /$ person/year (Wakchaure 2011).

World mushroom production (FAOStat 2015) is continously increasing, from 0.30 to 7.2 million tons over the last 50 years, from 1961 to 2012 (Figure 2.6), in line with exports/imports that showed a marginal increase up to 1985 and a tremendous increase beyond that up to 2012. Poland, The Netherlands, Ireland, China, Belgium, Lithuania, Canada, and USA are the major mushroom-exporting countries while countries including UK, Germany, France, The Netherlands, Belgium, Russian Federation, and Japan are the major importers. Processed mushroom (canned and dried) export is continuously increasing, from 0.049 to 0.683 million tons over the period of the last four decades (1970 - 2010), compared to fresh mushroom exports (0.014 to 0.482 million tons), but fluctuations in export are higher for processed mushrooms. In the USA, five decades ago, $75 \%$ of mushroom consumption was in the form of canned product. Today, canned mushroom contributes only $15 \%$ of total mushroom consumption. The consumption of canned mushroom is static and that of fresh mushroom has increased continuously. This clearly shows that consumers are interested in shifting towards fresh mushroom consumption (Wakchaure 2011).

The European Union mushroom production was about $24 \%$ of world production in 2012 (FAOStat 2015). Italy is the largest producer, Poland is the largest exporter, UK the largest importer; France and Spain are also among the larger European producers as well as consumers. Per capita consumption in these countries is very high (about $3.5 \mathrm{~kg}$ ) (Wakchaure 2011). Highest per capita consumption of mushroom is in The Netherlands $(11.62 \mathrm{~kg})$ followed by Ireland $(6.10 \mathrm{~kg})$ and Belgium $(4.46 \mathrm{~kg})$. As a comparison of different patterns of consumption, the per capita consumption of mushroom in India increased from $25 \mathrm{~g}$ to $40 \mathrm{~g}$ in the 10 years $1996-2007$. However, Indian estimates of per

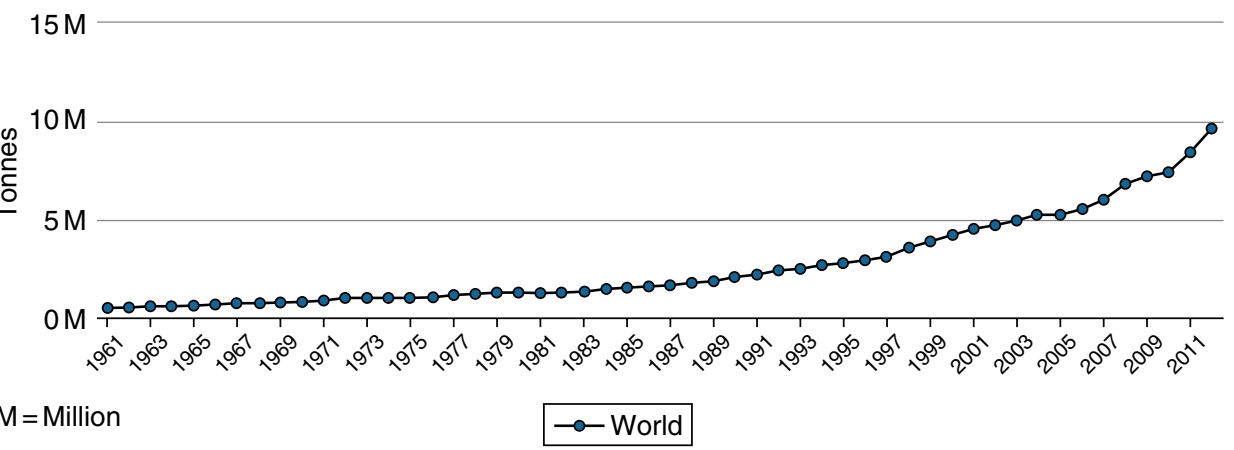

Figure 2.6 Mushroom and truffle world production from 1961 to 2012. Source: data from FAOStat (2015). 
capita consumption are about $90 \mathrm{~g}$, which is still much less compared to other countries including the USA (1.49 kg) and China (1.16 kg) (Wakchaure 2011).

A case study from a region of Spain where management of mycological resources has been regulated since 2003, Castilla and Leon, showed the number of species with potential economical interest beyond the species quantified by FAOStat data and the importance of the direct and indirect profits coming from mushrooms (Table 2.8). The production of Castilla and Léon Province is up to 31.466 tons per year, with an associated direct income of $80160 \mathrm{M} €$ and an indirect profit from micotourism around $4650724 €$ (see Table 2.8) (Martinez-Peña et al. 2011).

It is clear from the above that the EU and USA are the biggest markets and Poland and China are the biggest competitors in the mushroom market (Wakchaure 2011). These production and commercialization values are underestimated if we consider all the remaining species not quantified by FAOStat but collected and commercialized around the world as shown by the Spanish data.

Table 2.8 Wild edible mushroom production (except truffles), commercialization and economical value (including micotourism) in the province of Castille and Leon, Spain (Martinez-Peña 2011).

\begin{tabular}{lcccc}
\hline Edible species & $\begin{array}{l}\text { Production } \\
\text { (tonnes) }\end{array}$ & $\begin{array}{l}\text { Economical } \\
\text { value } €(\times 1000)\end{array}$ & $\begin{array}{l}\text { Micotourism } \\
\text { income }(\boldsymbol{\epsilon})\end{array}$ & $\begin{array}{l}\text { FTE } \\
\text { micotourism }\end{array}$ \\
\hline Agaricus spp. & 735 & 4.735 & - & - \\
Amanita caesarea (Scop.) Pers. & 1972 & 8.322 & - & - \\
Boletus aereus Bull. & 1879 & 7.683 & - & - \\
Boletus reticulatus Schaeff. & 328 & 1.263 & - & - \\
Boletus edulis Bull. & 1564 & 6.021 & - & - \\
Boletus pinophilus Pilát \& Dermek & 1035 & 6.292 & - & - \\
Calocybe gambosa (Fr.) Donk & 23 & 187 & - & - \\
Cantharellus cibarius Fr. & 324 & 2.268 & - & - \\
Helvella spp. & 26 & 26 & - & - \\
Hygrophorus marzuolus (Fr.) Bres. & 589 & 4.596 & - & - \\
Hygrophorus spp. & 9830 & 9.830 & - & - \\
Lactarius deliciosus (L. ex Fr.) S.F. & 5522 & 16.622 & - & - \\
Gray & & & & - \\
Lepista spp. & 1248 & 1.248 & - & - \\
Macrolepiota spp. & 591 & 591 & - & - \\
Marasmius oreades (Bolton) Fr. & 86 & 432 & - & - \\
Morchella spp. & 613 & 6.131 & - & - \\
Pleurotus eryngii (DC.) Quél & 317 & 1.558 & - & - \\
Tricholoma portentosum (Fr.) Quél. & 786 & 2.358 & $\mathbf{1 8 0}$ \\
TOTAL & $\mathbf{3 1 . 4 6 6}$ & $\mathbf{8 0 . 1 6 0}$ & $\mathbf{4 . 6 5 0 . 7 2 4}$ & - \\
\hline & & & & - \\
\hline
\end{tabular}

FTE, full-time equivalent. 


\subsection{Conclusion}

Fungi are an ancient group of organisms and their earliest fossils are from the Ordovician, 460-455 million years old (Redecker et al. 2000). Based on fossil evidence, the earliest vascular land plants appeared approximately 425 million years ago, and it is believed that fungi may have played an essential role in the colonization of land by these early plants.

Estimates for the number of fungi species in the world ranges from 3.5 to 5.1 million species and the Dictionary of the Fungi (Kirk et al. 2008) reported 98998 species of all described fungi.

Since time immemorial, a considerable number of identified species of fungi have made a significant contribution to human food and medicine.

The major features of wild edible fungi based on the first global assessment by the FAO (2004) are:

- 2327 wild useful species recorded; 2166 are edible and 1069 used as food, with at least 100 other "known food" species still lacking published studies

- 470 species have medicinal properties, of which 133 are neither eaten or said to be edible; a further 181 species have other properties and uses valued by people, e.g. religious, as tinder

- they are collected, consumed, and sold in over 80 countries worldwide

- amounts collected each year globally are several million tons with a minimum value of US\$2 billion, which has consistently increased since the first FAO records in 1961 (FAOStat 2015).

The major benefits of wild edible fungi are:

- valuable sources of nutrition, often with associated health benefits

- important source of income for local communities and national economies

- key species being ectomycorrhizal and helping to sustain tree growth and healthy forests

- being particularly valuable to rural people in developing countries.

The most important topics that need further investigation in mycology include diet, fungal ecology (mycorrhizas), and storage. How to manage wild edible fungi, to achieve sustainable production for both commercial harvesting and subsistence uses are key issues that need more work to support effective management.

Some factors related to mushroom biodiversity have been discussed, starting with the origin and diversity of fungi, through ecological diversity and diversity of habitats and global diversity of soil fungi, to finally focus on wild edible fungi, their diversity and social and economic interest. Cultivation aspects were also referred to, both concerning edible and medicinal fungi that can be cultivated and the general features of cultivation of edible fungi. Edible mushroom world production and commercialization were also presented with a statistical approach to FAOStat data from 1997 to 2012.

The main priorities of research on wild edible fungi are currently much the same as they were in the FAO 2004 report:

1) identification of species

2) nutritional status 
3) mycorrhizae

4) storage

5) effective management

6) nutraceutical and medicinal applications.

Our research group has been intensively working and publishing on topics 2, 3, 4, and 6 .

\section{References}

Aaronson, S. (2000) Fungi. In: K.F. Kiple \& K.C. Ornelas, eds. The Cambridge World History of Food. Cambridge: Cambridge University Press, 1958, pp 313-336.

Abdel-Azeem, A. M. (2010) The history, fungal biodiversity, conservation, and future perspectives for mycology in Egypt. IMA Fungus 1, 123-142.

Adhikari, M. K. (1999) Wild Relatives of Some Arable Mushrooms Found in Nepal. Presented at the National Conference on Wild Relatives of Cultivated Plants in Nepal. Kathmandu: Green Energy Mission, pp 149-155.

Adhikari, M. K. \& Durrieu, G. (1996) Ethnomycologie Nepalaise. Bulletin Societé Mycologique de France 112, 31-41.

Adl, S. M., Leander, B. S., Simpson, A. G. B., et al. (2007) Diversity, nomenclature, and taxonomy of Protists. Systematic Biology 56, 684-689.

Afyon, A. (1997) Macrofungi of Seydisehir district (Konya). Turkish Journal of Botany 21(3), 173-176.

Al-Naama, N. M., Ewaze, J. O. \& Nema, J. H. (1988) Chemical constituents of Iraqi truffles. Iraqi Journal of Agricultural Sciences 6, 51-56.

Alofe, F. V., Odeyemi, O. \& Oke, O. L. (1996) Three edible wild mushrooms from Nigeria: their proximate and mineral composition. Plant Foods for Human Nutrition 49, 63-73.

Alsheikh, A. M. \& Trappe, J. M. (1983) Desert truffles: the genus Tirmania. Transactions of the British Mycological Society 81, 83-90.

Alves, M. J., Ferreira, I. C. F. R., Dias, J., Teixeira, V., Martins, A. \& Pintado, M. (2012) A review on antimicrobial activity of mushroom (Basidiomycetes) extracts and isolated compounds. Planta Medica 78, 1707-1718.

Amato, P., Doyle, S. M. \& Christner, B. C. (2009) Macromolecular synthesis by yeasts under frozen conditions. Environmental Microbiology 11, 589-596.

Anguix, J. C. (2011) El Cultivo de Ongos Saprobios. In: Martinez-Peña F., Oria de Rueda, J. A. \& Ágreda, T., eds. Manual para la Gestión del Recurso Micológico Forestal en Castilla y León. Valladolid: Junta de Castilla y Léon, pp 296-299.

Antonin, V. \& Fraiture, A. (1998) Marasmius heinemannianus, a new edible species from Benin, West Africa. Belgian Journal of Botany 131, 127-132.

Arnold, A. E. (2007) Understanding the diversity of foliar endophytic fungi: progress, challenges, and frontiers. Fungal Biology Reviews 21, 51-66.

Arnold, A. E. \& Lutzoni, F. (2007) Diversity and host range of foliar fungal endophytes: are tropical leaves biodiversity hotspots? Ecology 88, 541-549.

Arnold, A. E., Mejía, L. C., Kyllo, D., et al. (2003) Fungal endophytes limit pathogen damage in leaves of a tropical tree. Proceedings of the National Academy of Sciences USA 100, 15649-15654.

Arora, D. (1986) Mushrooms Demystified. Berkeley: Ten Speed Press. 
Arora, D. (2008) The houses that matsutake built. Economic Botany 62(3), 278-290.

Barron, G. L. (1977) The Nematode-Destroying Fungi. Guelph: Canadian Biological Publications.

Batra, L. R. (1983) Edible discomycetes and gasteromycetes of Afghanistan, Pakistan and north-western India. Biologia (Lahore) 29, 293-304.

Berbee, M. L. \& Taylor, J. W. (2010) Dating the molecular clock in fungi - how close are we? Fungal Biology Reviews 24, 1-16.

Bhadury, P., Mohammad, B. T., \& Wright, P. C. (2006) The current status of natural products from marine fungi and their potential as antiinfective agents. Journal of Industrial Microbiology and Biotechnology 33, 325-337.

Binder, M., Hibbett, D. S., Wang, Z. \& Farnham, W. F. (2006) Evolutionary relationships of Mycaureola dilseae (Agaricales), a basidiomycete pathogen of a subtidal rhodophyte. American Journal of Botany 93, 547-556.

Birks, A. A. (1991) Fungi in folk medicine. McIlvainea 10(1), 89-94.

Bisby, G.R. \& Ainsworth, G.C. (1943) The numbers of fungi. Transactions of the British Mycological Society 26, 16-19.

Blackwell, M. (2011) The Fungi: 1, 2, 3...5.1 million species? American Journal of Botany 98, 426-438.

Boa, E. R. (2002) How do local people make use of wild edible fungi? Personal narratives from Malawi. In: I.R. Hall, Y. Wang, A. Zambonelli \& E. Danell, eds. Edible Ectomycorrhizal Mushrooms and Their Cultivation. Proceedings of the Second International Conference on Edible Ectomycorrhizal Mushrooms, July 2001, Christchurch. Christchurch: New Zealand Institute for Crop and Food Research Limited.

Boa, E. R., Ngulube, M. Meke, G. \& Munthali, C. (2000) First Regional Workshop on Sustainable Use of Forest Products: Miombo Wild Edible Fungi. Zomba, Malawi: Forest Research Institute of Malawi and CABI Bioscience.

Bokhary, H. A. \& Parvez, S. (1993. Chemical composition of desert truffles Terfezia claveryi. Journal of Food Composition and Analysis 6(3), 285-293.

Boruah, P., Adhikary, R. K., Kalita, P. \& Bordoloi, D. (1996) Some edible fungi growing in the forest of East Khasi Hills (Meghalaya). Advances in Forestry Research in India 14, 219.

Bouriquet, G. (1970) Les principaux champignons de Madagascar. Terre Malagache 7, 10-37.

Buller, A. H. R. (1914) The fungus lores of the Greeks and Romans. Transactions of the British Mycological Society 5, 21-66.

Burkhill, I. H. (1935) A Dictionary of the Economic Products of the Malay Peninsula. London: Crown Agents for the Colonies.

Buyck, B. (1994) Ubwoba: Les Champignons Comestibles de l'Ouest du Burundi. Brussels: Administration Generale de la Cooperation au Developpement.

Caglarirmak, N., Unal, K. \& Otles, S. (2002) Nutritional value of wild edible mushrooms collected from the Black Sea region of Turkey. Micologia Aplicada International 14(1), 1-5.

Cao, J. (1991) A new wild edible fungus - Wynnella silvicola. Zhongguo Shiyongjun (Edible Fungi of China) 10(1), 27-28.

Carris, L. M., Little, C. R. \& Stiles, C. M. (2012) Introduction to Fungi. The Plant Health Instructor. Available at: hwww.apsnet.org/edcenter/intropp/pathogengroups/pages/ introfungi.aspx (accessed 13 June 2016). 
Cavalier-Smith, T. (1998) A revised six-kingdom system of life. Biological Review 73, 203-266.

Cervera, M. \& Colinas, C. (1997) Comercialización de seta silvestre en la ciudad de Lleida. In F. Puertas \& M. Rivas, eds. Actas del I Congreso Forestal Hispano Luso, II Congreso Forestal Espanol-IRATI. Pamplona, Spain, 23-27 June 1997, pp 425-429.

Chamberlain, M. (1996) Ethnomycological experiences in South West China. Mycologist 10, 13-16.

Chang, S. T. (1999) World production of cultivated edible and medicinal mushrooms in 1997 with emphasis on Lentinus edodes in China. International Journal of Medicinal Mushrooms 1, 291-300.

Chang, S. T. \& Buswell, J. A. (1999) Ganoderma lucidum - a mushrooming medicinal mushroom. International Journal of Medicinal Mushrooms 1, 139-146.

Chang, S. T. \& Mao, X. (1995) Hong Kong Mushrooms. Hong Kong: Chinese University of Hong Kong.

Chang, S. T. \& Miles, P. G. (1989) Mushrooms: Cultivation, Nutritional Value, Medicinal Effect, and Environmental Impact. Boca Raton: CRC Press, pp 4-6.

Clay, K., Marks, S. \& Cheplick, G. P. (1993) Effects of insect herbivory and fungal endophyte infection on competitive interactions among grasses. Ecology 74, 1767-1777.

Crous, P. W., Rong, I. H., Wood, A., et al. (2006) How many species of fungi are there at the tip of Africa? Studies in Mycology 55, 13-33.

Davies, J. S. \& Westlake, D. W. S. (1979) Crude oil utilization by fungi. Canadian Journal of Microbiology 25, 146-156.

De Kesel, A., Codjia, J. T. C. \& Yorou, S. N. (2002) Guide des Champignons Comestibles du Bénin. Cotonou, République du Bénin: Jardin Botanique National de Belgique et Centre International d'Ecodéveloppement Intégré.

Degreef, J., Malaisse, E, Rammeloo, J. \& Baudart, E. (1997) Edible mushrooms of the Zambezian woodland area: a nutritional and ecological approach. BASE - Biotechnologie, Agronomie, Societe et Environnement 1, 221-231.

Demirbas, A. (2000) Accumulation of heavy metals in some edible mushrooms from Turkey. Food Chemistry 68, 415-419.

Deschamps, J. R. (2002) Hongos Silvestres Comestibles del Mercosur Con Valor Gastronómico. Documentos de Trabajo No. 86. Argentina: Universidad de Belgrano.

Dong, M. \& Shen, A. (1993) Studies on Lactarius camphoratus. 1 Biological characteristics of L. camphoratus. Zhongguo Shiyongjun (Edible Fungi of China) 12(1), 3-5.

Ducousso, M., Ba, A. M. \& Thoen, D. (2002) Ectomycorrhizal fungi associated with native and planted tree species in West Africa: a potential source of edible mushrooms. In: I.R. Hall, Y. Wang, A. Zambonelli \& E. Danell, eds. Edible Ectomycorrhizal Mushrooms and Their Cultivation. Proceedings of the Second International Conference on Edible Ectomycorrhizal Mushrooms, July 2001, Christchurch. Christchurch: New Zealand Institute for Crop and Food Research Limited.

EI'chibaev, A. A. (1964) S'edobnye griby Kirgizii [Edible Mushrooms of the Kirghiz SSR]. Kirgizskoi SSR, Izdatel'stvo Akademii Nauk.

Ejelonu, O. C., Akinmoladun, A. C., Elekofehinti, O. O. \& Olaleye, M. T. (2013) Antioxidant profile of four selected wild edible mushrooms in Nigeria. Journal of Chemical and Pharmaceutical Research 7, 286-245.

Ereifej, K. I. \& Al-Raddad, A. M. (2000) Identification and quality evaluation of two wild mushrooms in relation to Agaricus bisporus from Jordan. In: L.van Griensven, ed. 
Science and Cultivation of Edible Fungi. Proceedings of the 15th International Congress on the Science and Cultivation of Edible Fungi, Maastricht, Netherlands, 15-19 May 2000, pp 721-724.

Etkin, N. L. \& Johns, T. (1998) "Pharmafoods" and "Nutraceuticals": paradigm shifts in biotherapeutics. In H. V. Prendergast, N. L. Etkin, D. R. Harris \& P. J. Houghton, eds. Plants for Food and Medicine. London: Royal Botanic Gardens, pp 3-16.

FAO (1993) International Trade in Non-wood Forest Products: An Overview (M. Iqbal). Working Paper Misc/93/11. Rome: Food and Agriculture Organization.

FAO (1998) Non-wood Forest Products from Conifers (W.M. Ciesla). Rome: Food and Agriculture Organization.

FAO (2001) Non-wood Forest Products in Africa: A Regional and National Overview (S. Walter). Rome: Food and Agriculture Organization.

FAO (2004) Wild Edible Fungi: A Global Overview of their Use and Importance to People (E.R. Boa). Rome: Food and Agriculture Organization.

FAO (2009) Make Money Growing Mushrooms (E. Marshall and N. G. Nair). Rural Infrastructure and Agro-Industries Division. Rome: Food and Agriculture Organization.

FAOStat (2015) Available at: http://faostat.fao.org/site/567/DesktopDefault. aspx?PageID=567\# ancor (accessed 13 June 2016).

Fernandes, A., Barreira, J. C. M., Antonio, A. L., et al. (2015) Exquisite wild mushrooms as a source of dietary fiber: analysis in electron-beam irradiated samples. $L W T$ - Food Science and Technology 60, 855-859.

Fernández-Toirán, L. M., Ágreda, T., Águeda, B. \& Martínez-Peña, F. (2011a) Características generales de los hongos. In: Martinez-Peña F., Oria de Rueda, J. A. \& Ágreda, T., eds. Manual para la Gestión del Recurso Micológico Forestal en Castilla y León. Valladolid: Junta de Castilla y Léon, pp 32-39.

Fernández-Toirán, L. M., Ágreda, T, Águeda, B. \& Martínez-Peña, F. (2011b) Los hongos en el funcionamiento de los ecosistemas forestales. In: Martinez-Peña F., Oria de Rueda, J. A. \& Ágreda, T., eds. Manual para la Gestión del Recurso Micológico Forestal en Castilla y León. Valladolid: Junta de Castilla y Léon, pp 40-43.

Ferreira, I.C.F.R., Barros, L. \& Abreu, R.M.V. (2009) Antioxidant in wild mushrooms. Current Medicinal Chemistry 16, 1543-1560.

Ferreira, I. C. F. R., Vaz, J. A., Vasconcelos, M. H. \& Martins, A. (2010) Compounds from wild mushrooms with antitumor potential. Anti-Cancer Agents in Medicinal Chemistry 10, 424-436.

Feuerer, T. \& Hawksworth, D. L. (2007) Biodiversity of lichens, including a world-wide analysis of checklist data based on Takhtajan's floristic regions. Biodiversity and Conservation 16, 85-98.

Fierer, N., Strickland, M. S., Liptzin, D., Bradford, M. A. \& Cleveland, C. C. (2009) Global patterns in belowground communities. Ecology Letters 12, 1238.

Flores, R., Bran, M. d. C. \& Honrubia, M. (2002) Edible mycorrhizal mushrooms of the west Highland Guatemala. In: I.R. Hall, Y. Wang, A. Zambonelli \& E. Danell, eds. Edible Ectomycorrhizal Mushrooms and Their Cultivation. Proceedings of the Second International Conference on Edible Ectomycorrhizal Mushrooms, July 2001, Christchurch. Christchurch: New Zealand Institute for Crop and Food Research Limited.

Frank, B. (1885) Über die auf Wurzelsymbiose beruhende Ernährung gewisser Bäume durch unterirdische Pilze. Berichte der Deutschen Botanischen Gesellschaft 3, 128-145. 
Gamundí, I. \& Horak, E. (1995) Fungi of the Andean-Patagonian Forests. Buenos Aires: Vazquez Mazzini Editores.

Gardezi, R. A. (1993) Agaric fungi from Rawalakot, Azad Kashmir. Sarhad Journal of Agriculture 8(3), 225-226.

Gong, C. L. \& Peng, G. P. (1993) Culture of Cordyceps militaris on Chinese silkworms and the analysis of its components. Zhongguo Shiyongjun (Edible Fungi of China) 12(4), 21-23.

Hall, I. R., Buchanan, P. K., Wang, Y. \& Cole, A. L. J. (1998) Edible and Poisonous Mushrooms: An Introduction. Christchurch: New Zealand Institute for Crop and Food Research Limited.

Härkönen, M. (2002) Mushroom collecting in Tanzania and Hunan (southern China): inherited wisdom and folklore of two different cultures. In: R. Watling, J. C. Frankland, A. M. Ainsworth, S. Isaac \& C. H. Robinson, eds. Tropical Mycology, vol. 1 Macromycetes. Wallingford: CAB International, pp 149-165.

Härkönen, M., Saarimaki, T. \& Mwasumbi, L. (1994a) Edible and poisonous mushrooms of Tanzania. African Journal of Mycology and Biotechnology 2(2), 99-123.

Härkönen, M., Saarimäki, T. \& Mwasumbi, L. (1994b) Tanzanian mushrooms and their uses. 4. Some reddish edible and poisonous Amanita species. Karstenia 34, 47-60.

Harsh, N. S. K., Tiwari, C. K. \& Rai, B. K. (1996) Forest fungi in the aid of tribal women of Madhya Pradesh [India]. Sustainable Forestry 1, 10-15.

Hawksworth, D. L. (1991) The fungal dimension of biodiversity: magnitude, significance, and conservation. Mycological Research N, 641-655.

Hawksworth, D. L. (2001) The magnitude of fungal diversity: the 1.5 million species estimate revisited. Mycological Research 105,1422-1432.

Hawksworth, D. L. \& Kalin-Arroyo, M. T. (1995) Magnitude and distribution of biodiversity. In: V. Heywood, ed. Global Biodiversity Assessment. Cambridge: Cambridge University Press, pp 107-191.

Hawksworth, D. L. \& Rossman, A. Y. (1997) Where are all the undescribed Fungi? Phytopathology 87, 888-891.

He, X. (1991) Verpa bohemica - a seldom known and delicious edible fungus. Zhongguo Shiyongjun (Edible Fungi of China) 10(6), 19.

Held, B. W., Jurgens, J. A., Arenz, B. E., Duncan, S. M., Farrell, R. L. \& Blanchette R. A. (2005) Environmental factors influencing microbial growth inside the historic huts of Ross Island, Antarctica. International Biodeterioration and Biodegradation 55, 45-53.

Heleno, S. A., Barros, L., Martins, A., et al. (2015) Chemical composition, antioxidant activity and bioaccessibility studies in phenolic extracts of two Hericium wild edible species. LWT - Food Science and Technology 63, 475-481.

Hibbett, D. S., Binder, M. \& Wang, Z. (2003) Another fossil agaric from Dominican amber. Mycologia 95, 685-687.

Hibbett, D. S., Binder, M., Bischoff, J. F. et al. (2007) A higher-level phylogenetic classification of the Fungi. Mycological Research 111, 509-547.

Hillebrand, H. (2004) On the generality of the latitudinal diversity gradient. American Naturalist 163, 192-211.

Huang, N. (1989) New method of increasing production on Rhizopogon piceus in the south of Fujian Province. Zhongguo Shiyongjun (Edible Fungi of China) 8(5), 8-9.

Hughes, D. P., Anderson, S., Hywel-Jones, N. L., Himaman, W., Billen, J. \& Boomsma, J. J. (2011) Behavioral mechanisms and morphological symptoms of zombie ants dying from fungal infection. BMC Ecology 11, 1-13. 
Hyde, K. D. (1996) Measuring biodiversity: diversity of microfungi in north Queensland. In: T. Boyle \& B. Boontawee, eds. Measuring and Monitoring Biodiversity in Tropical and Temperate Forests. Bogor: CIFOR, pp 271-286.

Hyde, K. D., Fröhlich, J. \& Taylor, J. E. (1997) Diversity of ascomycetes on palms in the tropics. In: K. D. Hyde, ed. Biodiversity of Tropical Microfungi. Hong Kong: Hong Kong University Press, pp 141-156.

Hyde, K. D., Jones, E. B. G., Leaño, E., Pointing, S. B., Poonyth, A. D. \& Vrijmoed, L.L.P. (1998) Role of fungi in marine ecosystems. Biodiversity and Conservation 7, 1147-1161.

Iordanov, D., Vanev, S. G. \& Fakirova, V. I. (1978) Gubite y Bulgariya: Opredelitel na nairazprostranenite yadlivi i otrovni gubi [Fungi of Bulgaria: Keys to the Identification of the Most Widely Distributed Edible and Poisonous Fungi]. Sofiya: Izd-vo na Bulg. Akad. na Naukite.

Jahn, T. L. \& Jahn, F. F. (1949) How to Know the Protozoa. Dubuque: Wm C. Brown.

James, T. Y., Kauff, F., Schoch, C. L., et al. (2006) Reconstructing the early evolution of the fungi using a six gene phylogeny. Nature 443, 818-822.

Jones, E. B. G., Whalley, A. J. S. \& Hywel-Jones, N. L. (1994) A fungus foray to Chiang Mai market in Northern Thailand. Mycologist 8(2), 87-90.

Joppa, L. N., Roberts, D. L. \& Pimm, S. L. (2010) How many species of flowering plants are there? Proceedings of the Royal Society of London, B, Biological Sciences 278, 554-559.

Jordan, P. (2006) Field Guide to Edible Mushrooms of Britain and Europe. London: New Holland Publishers.

Kalac, P. (2009) Chemical composition and nutritional value of European species of wild growing mushrooms: a review. Food Chemistry 113, 9-6.

Kalac, P. (2012) Chemical composition and nutritional value of European species of wild growing mushrooms. In: S. Andres \& N. Baumann, eds. Mushrooms: Types, Properties and Nutrition. New York: Nova Science Publishers, pp 130-151.

Kalac, P. (2013) A review of chemical composition and nutritional value of wildgrowing and cultivated mushrooms. Journal of the Science of Food and Agriculture 93, 209-218.

Kalotas, A. (1997) Aboriginal knowledge and use of fungi. In: Fungi of Australia, vol. $1 B$. Introduction: Fungi in the Environment. Canberra: Australian Biological Resources Study, pp 269-295.

Katende, A. B., Segawa, P. \& Birnie, A. (1999) Wild Food Plants and Mushrooms of Uganda. Nairobi: Regional Land Management Unit, Swedish International Development Cooperation Agency.

Kim, H. \& Song, M. J. (2014) Analysis of traditional knowledge for wild edible mushrooms consumed by residents living in Jirisan National Park (Korea). Journal of Ethnopharmacology 153 90-97.

Kim, K. \& Harvell, C. D. (2004) The rise and fall of a six year coral fungal epizootic. American Naturalist 164, S52-S63.

Kirk, P. M., Cannon, P. F., David, J. C. \& Stalpers, J. A. (2001) Dictionary of the Fungi, 9th edn. Wallingford: CAB International.

Kirk, P., Cannon, P. F., Minter, D. W. \& Stalpers, J. A. (2008) Ainswort E Bisby's Dictionary of the Fungi, 10th edn. Wallingford: CAB International.

Klironomos, J. N. \& Hart, M. M. (2001) Animal nitrogen swap for plant carbon. Nature 410, 651-652.

Knogge, W. (1996) Fungal infection of plants. Plant Cell 8, 1711-1722.

Kohlmeyer, J., Spatafora, J. W. \& Volkmann-Kohlmeyer, B. (2000) Lulworthiales, a new order of marine Ascomycota. Mycologia 92, 453-458. 
Kurtzman, C. P. \& Fell, J. W. (1998) The Yeasts, A Taxonomic Study, 4th edn. Amsterdam: Elsevier.

Kytovuori, I. (1989) The Tricholoma caligatum group in Europe and North Africa. Karstenia 28, 65-77.

Lee, S. C., Corradi, N., Doan, S., Dietrich, F. S., Keeling, P. J. \& Heitman, J. (2010) Evolution of the sex-related locus and genomic features shared in Microsporidia and Fungi. PLoS ONE 5: e10539.

Li, Z. P. (1994) Comparison of medicinal effect between wild Ganoderma applanatum and cultivated Ganoderma lucidum. Zhongguo Shiyongjun (Edible Fungi of China) 13(2), 8-9.

Lincoff, G. (2002) There are only a dozen basic groups. Mushroom, the Journal of Wild Mushrooming 20, 9-15.

Lincoff, G. \& Mitchel, D. H. (1977) Toxic and Hallucinogenic Mushroom Poisoning. A Handbook for Physicians and Mushroom Hunters. New York: Van Nostrand Reinhold.

Liu, P. G. (1990) Investigation of the edible mushroom resources of Mt. Daqing of Inner Mongolia. Zhongguo Shiyongjun (Edible Fungi of China) 9, 26-27.

Liu, W. P. \& Yang, H. R. (1982) An investigation of mushroom poisoning in Ninghua County during the last 20 years. Chinese Journal of Preventative Medicine 16, 226-228.

Locquin, M. (1954) Une chanterelle comestible de la Cote d'Ivoire: Hygrophoropsis mangenotii sp. nov. Journal d'Agriculture Tropicale et de Botanique Appliquée 1, 359-361.

Longcore, J.E., Pessier, A. P., \& Nichols, D. K. (1999) Batrachochytrium dendrobatidis gen. et sp. nov., a chytrid pathogenic to amphibians. Mycologia 91, 219-227.

Lopez, G. A., Cruz, J. M. M. \& Zamora-Martinez, M. C. (1992) Evaluación de la produccion de hongos comestibles silvestres en San Juan Tetla, Puebla. Ciclo 1992. In: Reunion Cientzfica Forestal y Agropecuaria. Coyocan, Mexico, pp 182-191.

Lowore, J. \& Boa, E. (2001) Bowa Markets: Local Practices and Indigenous Knowledge of Wild Edible Fungi. Egham: CABI Bioscience.

Lowy, B. (1974) Amanita muscaria and the Thunderbolt legend in Guatemala and Mexico. Mycologia 66, 189-191.

Lutzoni, F. \& Miadlikowska, J. (2009) Lichens. Current Biology 19, R502-R503.

Malyi, L. P. (1987) Resources of edible fungi in Belorussia [Belarus] and the possibility of their utilization. Rastitelo'nye Resursy 23(4), 532-536.

Mao, X. L. (2000) The Macrofungi of China. Beijing: Henan Science and Technology Press.

Markham, P. (1998) Fungal food in Fiji: a suspiciously familiar story. Mycologist 12 (1), 23-25.

Marles, R. J., Clavelle, C., Monteleone, L., Tays, N. \& Burns, D. (2000) Aboriginal Plant Use in Canada's Northwest Boreal Forest. Vancouver: University of British Columbia.

Martin, G. W. (1951) The numbers of fungi. Proceedings of the Iowa Academy of Science 58, $175-178$.

Martinez-Peña, F., Mallo, J. A., Gómez, R., Francés, D., Ortega-Martínez, P. \& Martín, A. (2011) MICODATA: modelo territorial de producción y aprovechamiento micológico en Castilla y León. In: Martinez-Peña F., Oria de Rueda, J. A. \& Ágreda, T., eds. Manual para la Gestión del Recurso Micológico Forestal en Castilla y León. Valladolid: Junta de Castilla y Léon, pp 296-299.

Martínez, A., Oria de Rueda, J. A. \& Martínez, P. (1997) Estudio Sobre La Potencialidad de Los Diferentes Usos del Bosque Para La Creación de Empleo y Actividad Económica en El 
Medio Rural de Castilla León. Valladolid: Junta de Castilla y León y Fondo Social Europeo.

Mata, G. (1987) Introducción a la etnomicología maya de Yucatán, el conocimiento de los hongos en Pixoy, Valladolid. Revista Mexicana Micología 3, 175-187.

McNeely, J. A., Miller, K. R., Mittermeier, R. and Werner, T. B. (1990) Conserving the World's Biological Diversity. Gland: International Union for Conservation of Nature and Natural Resources.

Minter, D., Cannon, P. F. \& Peredo, H. L. (1987) South America species of Cyttaria (a remarkable and beautiful group of edible ascomycetes). Mycologist 1, 7-11.

Mittelbach, G. G., Schemske, D. W., Cornell, H. V., et al. (2007) Evolution and the latitudinal diversity gradient: speciation, extinction and biogeography. Ecology Letters 10, 315-331.

Montoya-Esquivel, A. (1998) Ethnomycology of Tlaxcala, Mexico. McIlvainea 13(2), $6-12$.

Montoya-Esquivel, A., Estrada-Torres, A., Kong, A. \& Juarez-Sanchez, L. (2001) Commercialization of wild mushrooms during market days of Tlaxcala, Mexico. Micologia Aplicada International 13, 31-40.

Moore, R. T. (1980) Taxonomic proposals for the classification of marine yeasts and other yeast-like fungi including the smuts. Botanica Marina 23, 361-373.

Moreno-Arroyo, B., Recio, J. M., Gomez, J. \& Pulido, E. (2001) Tuber oligospermum from Morocco. Mycologist 15, 41-42.

Moreno-Fuentes, A., Cifuentes, J., Bye, R. \& Valenzuela, R. (1996) Kute-mo'ko-a: an edible fungus of the Raramuri Indians of Mexico. Revista Mexicana de Micología 12, 31-39.

Morris, P. J., Johnson, W. R., Pisanic, J., et al. (2011) Isolation of culturable microorganisms from free-ranging bottle nose dolphins (Tursiops truncatus) from the southeastern United States. Veterinary Microbiology 148, 440-447.

Mshigeni, K. E. \& Chang, S. T. (2000) A Guide to Successful Mushroom Farming: With Emphasis on Technologies Appropriate and Accessible to Africa's Rural and Peri-Urban Communities. UNDP/UNOPS Regional Project RAF/99/021. Windhoek: University of Namibia.

Mueller, G. M. \& Schmit, J. P. (2007) Fungal biodiversity: What do we know? What can we predict? Biodiversity and Conservation 16, 1-5.

Murdoch, M. E., Reif, J. S., Mazzoil, M., McCulloch, S. D., Fair, P. A. \& Bossart G. D. (2008) Lobomycosis in bottlenose dolphins (Tursiops truncatus) from the Indian River Lagoon, Florida: estimation of prevalence, temporal trends, and spatial distribution. EcoHealth 5, 289-297.

Nagahama, T. (2006) Yeast biodiversity in freshwater, marine and deepsea environments. In: C. Rosa \& P. Gábor, eds. Biodiversity and Ecophysiology of Yeasts. Berlin: SpringerVerlag, pp 241-262.

Namgyel, P. (2000) The story of Buddha mushroom, Tricholoma matsutake. Unpublished manuscript, Thimpu, Bhutan.

Novellino, D. (1999) The Ominous Switch: From Indigenous Forest Management to Conservation - The Case of the Batak on Palawan Island, Philippines. Copenhagen: IWGIA.

O’Brien, B. L., Parrent, J. L., Jackson, J. A., Moncalvo, J. M. \& Vilgalys, R. (2005) Fungal community analysis by large-scale sequencing of enviromental samples. Applied and Environmental Microbiology 71, 5544-5550. 
Ødegaard, F. (2000) How many species of arthropods? Erwin's estimate revised. Biological Journal of the Linnean Society 71, 583-597.

Oso, B. (1975) Mushrooms and the Yoruba people of Nigeria. Mycologia 67(2), 311-319.

Parfrey, L. W., Lahr, D. J. G., Knoll, A. H. \& Katz, L. A. (2011) Estimating the timing of early eukaryotic diversification with multigene molecular clocks. Proceedings of the National Academy of Sciences USA 108, 13624-13629.

Pauli, G. (1998) Qingyuan: the mushroom capital of the world. Available at: www.zeri.org/ news/1998/august/aug_chin.htm

Paton, A. J., Brummitt, N., Govaerts, R., et al. (2008) Towards Target 1 of the Global Strategy for Plant Conservation: a working list of all known plant species - progress and prospects. Taxon 57, 602-611.

Pegler, D. N. \& Piearce, G. D. (1980) The edible mushrooms of Zambia. Kew Bulletin 35, 475-491.

Pegler, D. N. \& Vanhaecke, M. (1994) Termitomyces of Southeast Asia. Kew Bulletin 49, 717-736.

Piearce, G. D. (1981) Zambian mushrooms - customs and folklore. Bulletin of the British Mycological Society 15(2), 139-142.

Pivkin, M. V., Aleshko, S. A., Krasokhin, V. B. \& Khudyakova, Y. V. (2006) Fungal assemblages associated with sponges of the southern coast of Sakhalin Island. Russian Journal of Marine Biology 32, 207-213.

Prance, G. (1984) The use of edible fungi by Amazonian Indians. Advances in Economic Botany 1, 127-139.

Pressel, S., Bidartondo, M.I., Ligrone, R. \& Duckett, J. G. (2010) Fungal symbioses in bryophytes: new insights in the twenty first century. Phytotaxa 9, 238-253.

Pringle, A. Bever, J. D., Gardes, M., Parrent, J.L., Rillig, M. C. \& Klironomos, J. N. (2009) Mycorrhizal symbioses and plant invasions. Annual Review of Ecology, Evolution, and Systematics 40, 699-715.

Purkayastha, R. P. \& Chandra, A. (1985) Manual of Edible Mushrooms. New Delhi: Today and Tomorrow's Printers and Publishers.

Rammeloo, J. (1994) The contributions of the national botanic garden of Belgium to the mycology of Africa. In: J.H. Seyani \& A.C. Chikuni, eds. Proceedings of the XIIIth Plenary Meeting of AETFAT, Zomba, Malawi, 2-11 April 1991, vol. 1. Zomba, Malawi: National Herbarium and Botanic Gardens of Malawi, pp 671-685.

Rammeloo, J. \& Walleyn, R. (1993) The edible fungi of Africa south of the Sahara: a literature survey. Scripta Botanica Belgica 5, 1-62.

Raspor, P. \& Zupan, J. (2006) Yeasts in extreme environments. In: C. Rosa \& P. Gábor, eds. Biodiversity and Ecophysiology of Yeasts. Berlin: Springer-Verlag, pp 372-417.

Remotti, C. D. \& Colan, J. A. (1990) Identification of wild edible fungi in Dantas Forest, Huanuco. Revista Forestal del Peru 17, 21-37.

Remy, W., Taylor, T. N., Hass, H. \& Kerp, H. (1994) Four hundred million-year-old vesicular arbuscular mycorrhizae. Proceedings of the National Academy of Sciences USA 91, 11841-11843.

Reshetnikov, S. V., Wasser, S. P. \& Tan, K.K. (2001) Higher basidiomycota as a source of antitumour and immunostimulating polysaccharides. A review. International Journal of Medicinal Mushrooms 3, 361-394.

Richardson, D. H. S. (1988) Medicinal and other economic aspects of lichens. In: M. Galun, ed. CRC Handbook on Lichenology, vol. 3. Boca Raton: CRC Press, pp 93-108. 
Richardson, D. H. S. (1991) Lichens and man. In: D. L. Hawksworth, ed. Frontiers in Mycology. Wallingford: CAB International, pp 187-210.

Rinaldi, A. C., Comandini, O. \& Kuyper, T. W. (2008) Ectomycorrhizal fungal diversity: separating the wheat from the chaff. Fungal Diversity 33, 1-45.

Rodriguez, R. J., White Jr., J. F., Arnold, A. E. \& Redman, R. S. (2009) Fungal endophytes: diversity and functional roles. New Phytologist 182, 314-330.

Rojas, C. \& Mansur, E. (1995) Ecuador: informaciones generales sobre productos non madereros en Ecuador. In: Memoria, Consulta de Expertos sobre Productos Forestales No Madereros para America Latina y el Caribe. Serie Forestal \#1. Santiago, Chile: FAO Regional Office for Latin America and the Caribbean, pp 208-223.

Rossman, A. (1994) A strategy for an all-taxa inventory of fungal biodiversity. In: C. I. Peng \& C. H. Chou, eds. Biodiversity and Terrestrial Ecosystems. Academia Sinica Monograph Series No. 14. Taiwan: Academia Sinica, pp 169-194.

Rubel, W. \& Arora, D. (2008) A study of cultural bias in field guide determinations of mushroom edibility using the iconic mushroom, Amanita muscaria, as an example. Botany 62 (3), 223-243.

Saar, M. (1991) Fungi in Khanty folk medicine. Journal of Ethnopharmacology 31, 175-179.

Sabra, A. \& Walter, S. (2001) Non-Wood Forest Products in the Near East: A Regional and National Overview. Working Paper FOPW/01/2. Rome: Food and Agriculture Organization.

Saenz, J. A., Lizano, A. V. M. \& Nassar, M. C. (1983) Edible, poisonous and hallucinatory fungi in Costa Rica. Revista de Biologia Tropical 31, 201-207.

Saikkonen, K., Faeth, S. H., Helander, M. \& Sullivan, T. J. (1998) Fungal endophytes: a continuum of interactions with host plants. Annual Review of Ecology and Systematics 29, 319-343.

Sarkar, B. B., Chakraborty, D. K. \& Bhattacharjee, A. (1988) Wild edible mushroom flora of Tripura. Indian Agriculturist 32, 139-143.

Schmeda-Hirschmann, G., Razmilic, I., Reyes, S., Gutierrez, M. I. \& Loyola, J. I. (1999) Biological activity and food analysis of Cyttaria spp. (Discomycetes). Economic Botany 53 (1), 30-40.

Schmit, J. P. \& Mueller, G. M. (2007) An estimate of the lower limit of global fungal diversity. Biodiversity and Conservation 16, 99-111.

Schüßler, A. \& Walker, C. (2010) The Glomeromycota. A Species List with New Families and New Genera. Royal Botanic Garden Edinburgh, Royal Botanic Garden Kew, Botanische Staatssammlung Munich, and Oregon State University. Available at: www. amf-phylogeny.com (accessed 13 June 2016).

Schüßler, A., Schwarzott, D. \& Walker, C. (2001) A new fungal phylum, the Glomeromycota: phylogeny and evolution. Mycological Research 105, 1413-1421.

Serna-Chavez, H., Fierer, N. \& van Bodegom, P. M. (2013) Global drivers and patterns of microbial abundance in soil. Global Ecology and Biogeography 22, 1162-1172.

Sharda, R. M., Kaushal, S. C. \& Negi, G. S. (1997) Edible fungi of Garhwal Himalayas. Mushroom Journal 1997, 11-13.

Sharma, Y. K. \& Doshi, A. (1996) Some studies on an edible wild fungus Phellorinia inquinans, in Rajasthan, India. Mushroom Research 5, 51-53.

Shearer, C.A. \& Raja, H. A. (2010) Freshwater ascomycetes database. Available at: http:// fungi.life.illinois.edu/(accessed 13 June 2016). 
Shearer, C. A., Descals, E., Kohlmeyer, B., et al. (2007) Fungal diversity in aquatic habitats. Biodiversity and Conservation 16, 49-67.

Sillitoe, P. (1995) Ethnoscientific observations on entomology and mycology in the southern highlands of Papua New Guinea. Science in New Guinea 21(1), 3-26.

Simmons, C., Henkel, T. \& Bas, C. (2002) The genus Amanita in the Pakaraima mountains of Guyana. Persoonia 17 (4), 563-582.

Singer, R. (1953) Four years of mycological work in southern South America. Mycologia 45, 865-891.

Singh, S. K. \& Rawat, G. S. (2000) Morel mushroom industry in India. Plant Talk 21, 36-37.

Smith, S. E. \& Read, D. J. (2008) Mycorrhizal Symbiosis, 3rd edn. San Diego: Academic Press.

Stamets, P. (2000) Growing Gourmet and Medicinal Mushrooms, 3rd edn. Berkeley: Ten Speed Press.

Stubblefield, S. P., Taylor, T. N. \& Trappe, J. M. (1987) Fossil mycorrhizae: a case for symbiosis. Science 237, 59-60.

Syed-Riaz, A. G. \& Mahmood-Khan, S. (1999) Edible mushrooms from Azad Jammu and Kashmir. Pakistan Journal of Phytopathology 11, 163-165.

Taylor, D. L., Herriott, I. C., Stone, K. E., McFarland, J. W., Booth, M. G. \& Leigh, M. B. (2010) Structure and resilience of fungal communities in Alaskan boreal forest soils. Canadian Journal of Forest Research 40, 1288-1301.

Taylor, F. W., Thamage, D. M., Baker, N., Roth-Bejerano, N. \& Kagan-Zur, V. (1995) Notes on the Kalahari desert truffle, Terfezia pfeillii. Mycological Research 99, 874-878.

Taylor, P. H. \& Gaines, S. D. (1999) Can Rapoport rule be rescued? Modelling causes of the latitudinal gradient in species richness. Ecology 80, 2474-2482.

Taylor, T. N. \& Taylor, E. L. (1993) The Biology and Evolution of Fossil Plants. New Jersey: Prentice Hall.

Taylor, T. N., Klavins, S. D., Krings, M., Taylor, E. L., Kerp, H. \& Hass, H. (2004a) Fungi from the Rhynie Chert: a view from the dark side. Transactions of the Royal Society of Edinburgh, Earth Sciences 94, 457-473.

Taylor, T. N., Hass, H., Kerp, H., Krings, M. \& Hanlin, R. T. (2004b) Perithecial ascomycetes from the 400 million year old Rhynie chert: an example of ancestral polymorphism. Mycologia 96, 1403-1419.

Taylor, T. N., Hass, H., Kerp, H., Krings, M., \& Hanlin, R. T. (2005) Perithecial ascomycetes from the 400 million year old Rhynie chert: an example of ancestral polymorphism. Mycologia 97(1), 269-285.

Tedder, S., Mitchell, D. \& Farran, R. (2002) Property Rights in the Sustainable Management of Non-Timber Forest Products. Victoria, British Columbia: British Columbia Ministry of Forests.

Tedersoo, L., Bahram, M., Põlme, S., et al. (2014) Global diversity and geography of soil fungi. Science 346, no. 6213. DOI: 10.1126/science.1256688

Thoen, D. \& Ba, A. M. (1989) Ectomycorrhizas and putative ectomycorrhizal fungi of Afzelia africana and Uapaca senegalensis in southern Senegal. New Phytologist 113, 549-559.

Tuno, N. (2001) Mushroom utilization by the Majangir, an Ethiopian tribe. Mycologist 15, 78-79. 
Uaciquete, A., Dai, M. d. L. \& Motta, H. (1996) Distribuição, Valor Económico e Uso Sustentável Dos Cogumelos Comestíveis em Moçambique [Distribution, Economic Value and Sustainable Use of Edible Mushrooms in Mozambique]. Maputo, Mozambique: Grupo de Trabalho Ambiental.

Vasil'eva, L. N. (1978) Edible Mushrooms of the Far East. Vladivostock: Far Eastern Publishing House.

Vega, F. E., Simpkins, A., Aime, M. C., et al. (2010) Fungal endophyte diversity in coffee plants from Colombia, Hawai'i, Mexico, and Puerto Rico. Fungal Ecology 3, 122-130.

Villarreal, L. \& Perez-Moreno, J. (1989) Los hongos comestibles silvestres de Mexico, un enfoque integral. Micologia Neotropica Aplicada 2, 77-114.

Vishniac, H. S. (2006) Yeast biodiversity in the Antarctic In: C. Rosa \& P. Gábor, eds. Biodiversity and Ecophysiology of Yeasts. Berlin: Springer-Verlag, pp 419-440.

Vogt, K. A., Bloomfield, J., Ammirati, J. F. \& Ammirati, S. R. (1992) Sporocarp production by basidiomycetes, with emphasis on forest ecosystems. In: Carroll GC, Wicklow DT, eds. The Fungal Community: Its Organization and Role in the Ecosystem. New York: Marcel Dekker, pp 563-581.

Wakchaure, G. C. (2011) Production and marketing of mushrooms: global and national scenario. In: M Singh, B. Vijay, S. Kamal \& G.C. Wakchaure, eds.

Mushrooms - Cultivation, Marketing and Consumption. Solan, Himachal Pradesh: Directorate of Mushroom Research, pp 15-22.

Walleyn, R. \& Rammeloo, J. (1994) The poisonous and useful fungi of Africa south of the Sahara: a literature survey. Scripta Botanica Belgica 10, 1-56.

Wang, B. \& Qiu, Y. L. (2006) Phylogenetic distribution and evolution of mycorrhizas in land plants. Mycorrhiza 16, 299-363.

Wang, G., Li, Q., \& Zhu, P. (2008) Phylogenetic diversity of culturable fungi associated with the Hawaiian sponges Suberites zeteki and Gelliodes fibrosa. Antonie van Leeuwenhoek 93, 163-174.

Wang, Y., Hall, I. R. \& Evans, L. A. (1997) Ectomycorrhizal fungi with edible fruiting bodies. 1. Tricholoma matsutake and related fungi. Economic Botany 51(3), 311-327.

Wang, Y. C. (1987) Mycology in ancient China. Mycologist 1, 59-61.

Wardle, D. A. \& Lindahl, B. D. (2014) Disentangling the global mycobiome. Science 346, 1052-1053.

Wasser, S. P. (1995) Edible and Poisonous Mushrooms of Israel. Tel-Aviv: Modan Press.

Wasser, S. P. \& Weis, A. L. (1999a) General description of the most important medicinal higher basidiomycetes mushrooms. 1. International Journal of Medicinal Mushrooms 1, 351-370.

Wasser, S. P. \& Weis, A. L. (1999b) Medicinal properties of substances occurring in higher basidiomycetes mushrooms: current perspectives (review). International Journal of Medicinal Mushrooms 1, 31-62.

Wasser, S. P., Nevo, E., Sokolov, D., Reshetnikov, S. \& Timor-Tismenetsky, M. (2000) Dietary supplements from medicinal mushrooms: diversity of types and variety of regulations. International Journal of Medicinal Mushrooms 2, 1-19.

Weir, A. \& Hammond, P. M. (1997a) Laboulbeniales on beetles: host utilization patterns and species richness of the parasites. Biodiversity and Conservation 6, 701-719.

Weir, A. \& Hammond, P. M. (1997b) A preliminary assessment of species-richness patterns of tropical, beetle-associated Laboulbeniales (Ascomycetes). In: K. D. Hyde, ed. 
Biodiversity of Tropical Microfungi. Hong Kong: Hong Kong University Press, pp 121-139.

White, M. M., James, T. Y., O’Donnell, K., Cafaro, M. J., Tanabe Y. \& Sugiyama J. (2006)

Phylogeny of the Zygomycota based on nuclear ribosomal sequence data. Mycologia 98, 872-884.

Whittaker, R. H. (1959) On the broad classification of organisms. Quarterly Review of Biology 34, 210-226.

Whittaker, R. H. (1969) New concepts of kingdoms of organisms. Science 163, 150-160.

Wilson, K., Cammack, D. \& Shumba, E (1989) Food Provisioning amongst Mozambican Refugees in Malawi. A Study of Aid, Livelihood and Development. A report prepared for the World Food Programme. Oxford: Oxford University.

Winkler, D. (2002) Forest use and implications of the 1998 logging ban in the Tibetan prefectures of Sichuan: Case study on forestry, reforestation and NTFP in Litang County, Ganzi TAP, China. In: Z. Ziang, M. Centritto, S. Liu \& S. Zhang, eds. The ecological basis and sustainable management of forest resources. Informatore Botanico Italiano 134 (Supplemento 2).

Wirtz, N., Printzen, C. \& Lumbsch, H. T. (2008) The delimitation of Antarctic and bipolar species of neuropogonoid Usnea (Ascomycota, Lecanorales): a cohesion approach of species recognition for the Usnea perpusilla complex. Mycological Research 112, 472-484.

Xiang, Y. T. \& Han, Z. (1987) Using sun-cured bed to increase temperature in the early spring for culturing straw mushroom (Volvariella esculenta). Zhongguo Shiyongjun (Edible Fungi of China) 6 (1), 16-17.

$\mathrm{Xu}, \mathrm{X}$., Thornton, P. \& Post, W. M. (2013) A global analysis of soil microbial biomass carbon, nitrogen and phosphorus in terrestrial ecosystems. Global Ecology and Biogeography 22, 737-749.

Yang, Z. (1990) A delicious tropical mushroom - Termitomyces heimii occurring in Yunnan, China. Zhongguo Shiyongjun (Edible Fungi of China) 9 (4), 28-30.

Yang, Z. (1992) Polyozellus multiplex - a rare edible fungus. Zhongguo Shiyongjun (Edible Fungi of China) 11 (2), 1-4.

Yang, Z. L. \& Yang, C. (1992) Recognition of Hypsizygus marmoreus and its cultivation. Zhongguo Shiyongjun (Edible Fungi of China) 11 (5), 19-20.

Yilmaz, F., Oder, N. \& Isiloglu, M. (1997) The macrofungi of the Soma (Manisa) and Savastepe (Balikesir) districts. Turkish Journal of Botany 21 (4), 221-230.

Yorou, S. N. \& de Kesel, A. (2002) Connaissances ethnomycologiques des peuples Nagot du centre du Benin (Afrique de l'Ouest). In: E. Robbrecht, J. Degreef \& I. Friis, eds. Plant Systematics and Phytogeography for the Understanding of African Biodiversity. Proceedings of the XVith AETFAT Congresss, 2000, Meise, National Botanic Garden of Belgium. Systematics and Geography of Plants 71, 627-637.

Yorou, S. N., de Kesel, A., Sinsin, B. \& Codjia, J. T. C. (2002) Diversité et productivité des champignons comestibles de la foret classée de Wari Maro (Benin). In: E. Robbrecht, J. Degreef \& I. Friis, eds. Plant Systematics and Phytogeography for the Understanding of African Biodiversity. Proceedings of the XVith AETFAT Congresss, 2000, Meise, National Botanic Garden of Belgium. Systematics and Geography of Plants 71, 613-625.

Zakhary, J. W., Abo-Bakr, T. M., El-Mandy, A. R. \& El-Tabery, S. A. M. (1983) Chemical composition of wild mushrooms collected from Alexandria, Egyptian Food Chemistry 11, $31-41$. 
Zaklina, M. (1998) Edible mycorrhizal mushrooms in serbia - problems with protection. Second International Conference on Mycorrhiza, Uppsala, Sweden, 5-10 July 1998.

Zamora-Martinez, M. C., Reygadas, G. F. \& Cifuentes, J. (1994) Hongos Comestibles Silvestres de la Subcuenca Arroya El Zorrillo, Distrito Federal. Coyoacan, DF Mexico: INIFAP.

Zamora-Martinez, M. C., Alvardo, G. \& Dominguez, J. M. (2000) Hongos Silvestres Comestibles region de Zacualtipan, Hidalgo. Pachuca, Mexico: INIFAP CIRCENTRO.

Zang, M. (1984) Mushroom distribution and the diversity of habitats in Tibet, China. McIlvainea 6 (2), 15-20.

Zang, M. (1988) An interesting edible mushroom: Agaricus gennadii. Zhongguo Shiyongjun (Edible Fungi of China) 7 (4), 3-4.

Zang, M. \& Doi, Y. (1995) Secotium jimalaicum sp. nov. from Nepal - a folklore concerning the food of abominable snowman. Acta Botanica Yunnanica 17(1), 30-32.

Zang, M. \& Petersen, R. (1990) An endemic and edible fungus - Endophyllus yunnanensis from China. Zhongguo Shiyongjun (Edible Fungi of China) 9(3), 3-5.

Zang, M. \& Pu, C. (1992) Confirmatory Tuber indica distributed in China. Zhongguo Shiyongjun (Edible Fungi of China) 11 (3), 19.

Zang, M. \& Yang, Z. L. (1991) Agrocybe salicacola, a delicious edible mushroom newly discovered from Yunnan. Zhongguo Shiyongjun (Edible Fungi of China) 10(6), 18.

Zerova, M. Y. \& Rozhenko, G. L. (1988) Atlas s'edobnykh i yadovitykh gribov [Atlas of Edible and Poisonous Fungi - Ukraine]. Kiev: Radyans'ka shkola.

Zhuang, Y. (1993) Characterization and textual criticism of Huai cr (Trametes robiniophila. Zhongguo Shiyongjun (Edible Fungi of China) 13 (6), 22-23.

Zhuang, Y. \& Wang, Y. S. (1992) Applied research for second nutrition of Gastrodia elata. Quality of Gastrodia elata with trace element Zn. Zhongguo Shiyongjun (Edible Fungi of China) 11 (6), 5-6. 